\title{
Performance enhancement of solar collectors-A review
}

\author{
Siddharth Suman, Mohd. Kaleem Khan*, Manabendra Pathak \\ Department of Mechanical Engineering, Indian Institute of Technology Patna, Patna 800013, India
}

\section{A R T I C L E I N F O}

\section{Article history:}

Received 13 May 2014

Received in revised form

20 March 2015

Accepted 23 April 2015

Available online 14 May 2015

\section{Keywords:}

Nanofluids

Solar selective

Coatings

Artificial roughness

Heat transfer

Ribs

\begin{abstract}
A B S T R A C T
Given rapid depletion of conventional energy sources and environmental degradation caused by their over exploitation, the renewable energy sources are believed to be the future. Technologies utilizing renewable energy sources differ significantly from one another, not only with regard to technical and economic aspects but also in relation to their reliability, maturity, and operational experience in utility scale conditions. Technologies used to harness solar energy have emerged as the most promising and mature since solar energy is abundant, freely available, and it has commercial potential too. This paper presents a review of advancements made in the field of solar thermal technology with a focus on techniques employed for its performance enhancement. It also covers the description of different types of solar collectors to facilitate the systematic understanding of solar thermal technology and the novel modifications realized in each category of solar collectors have been highlighted to promote the use of solar energy in routine activities. Performance enhancement techniques such as geometrical modifications on the absorber plate, use of solar selective coatings and nanofluids have been given a special attention.
\end{abstract}

(c) 2015 Elsevier Ltd. All rights reserved.

\section{Contents}

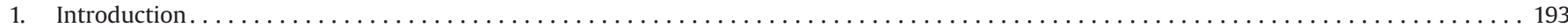

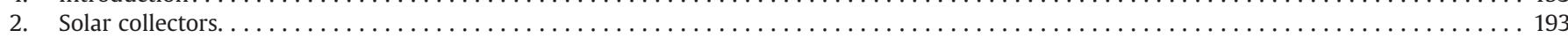

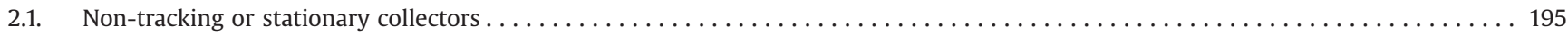

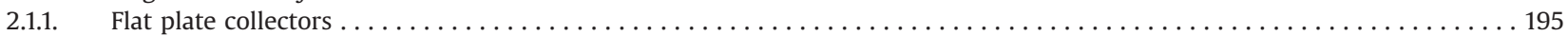

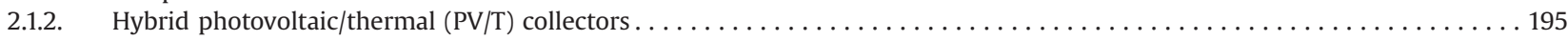

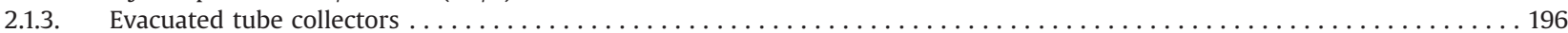

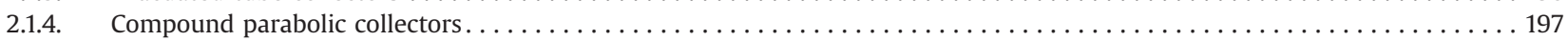

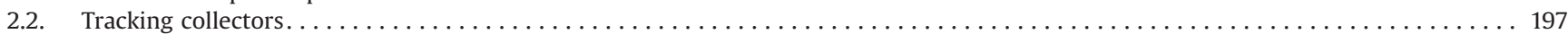

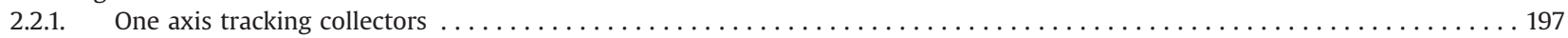

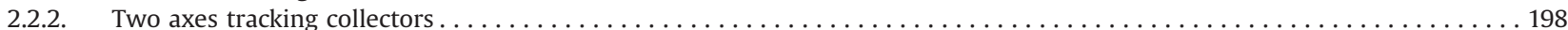

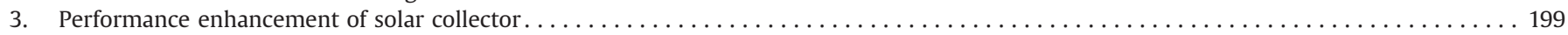

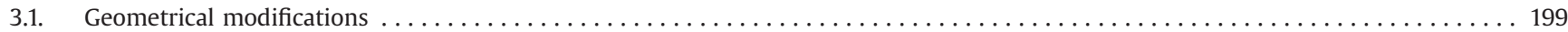

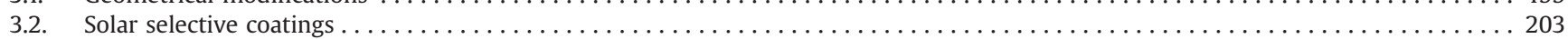

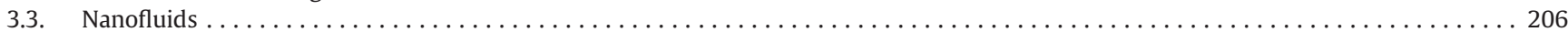

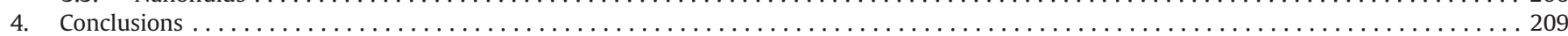

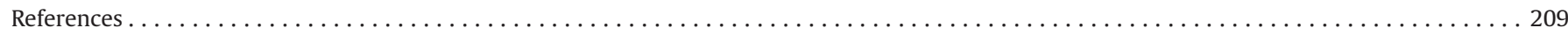

\footnotetext{
Abbreviations: BNNT, boron nitride nanotube; CNT, carbon nanotube; CR, concentration ratio; CRS, central receiver system; CSP, concentrated solar power; DC, direct current; ETC, evacuated tube collector; ICS, integrated collector storage; LDR, light dependent resistor; MWNT, multi-wall nanotube; PCM, phase change material; PECVD, plasma-enhanced chemical vapor deposition; PV, photovoltaic; PV/T, photovoltaic-thermal; PVD, physical vapor deposition; SAH, solar air heater; SS/SS-N, stainless steel/ stainless steel nitride; SWH, solar water heater; SWNT, single wall nanotube; TE, thermoelectric module; TPCT, two-phase closed thermosyphon

* Corresponding author. Tel.: +91612 2552019; fax: +91612 2277383.

E-mail addresses: mkkhan@iitp.ac.in, kalimdme@gmail.com (Mohd.K. Khan).
} 


\section{Introduction}

It is the age of machines-for either necessity or luxury. Machines need energy to perform tasks. Meeting the ever-increasing demand of energy without degrading the environment has always been concern of scientific community. Generation of energy from limited conventional sources has caused so much environmental degradation that impact is visible in the form of pollution, acid rain, global warming etc. Thus, there is a crying need for producing green and clean energy from renewable sources. Among all the renewable energy resources, the solar energy has emerged as one of the most promising renewable energy resource since it is abundant, freely available, and it has commercial potential too. The conversion of solar energy into different other forms is evident in nature, as shown in Fig. 1. The solar energy is converted into chemical energy by the process of photosynthesis in green plants. The conversion of solar energy into mechanical energy happens during the process of evaporation from water bodies, and change in wind behavior. In addition, there are two broad ways of utilizing the solar energy for the production of energy: (i) solar-electric conversion (converting solar energy directly into electrical energy using photovoltaic solar cell) and (ii) solar-thermal conversion (converting solar energy into thermal energy using solar collector).

A lot of research works have been reported in the literature on solar-thermal systems. A few important review articles highlighting these research works are mentioned in Table 1. Kalogirou [1] conducted an exhaustive review on different types of solar thermal collectors and their applications. The various types of collectors were discussed and presented with their optical, thermal and thermodynamic analysis. The applications of solar thermal systems in diverse areas of technology were illustrated to emphasize the need of its use whenever possible. Barlev et al. [2] presented a review on concentrating collectors, viz. parabolic trough collectors, heliostat field collectors, linear Fresnel reflector, parabolic dish collector etc. They suggested that concentrated solar power (CSP) technology could not only be used for electricity generation, but also for large range of other applications such as desalination of water, industrial heating and cooling, detoxification and disinfection of water etc. Other review articles, listed in Table 1, are focused on any particular type of collector or its specific application and have not discussed different techniques employed for the performance enhancement of solar collectors. For example, the methods like use of artificial roughness, solar selective coating, and nanofluids for enhancing the thermal performance of solar collectors have never been presented collectively.

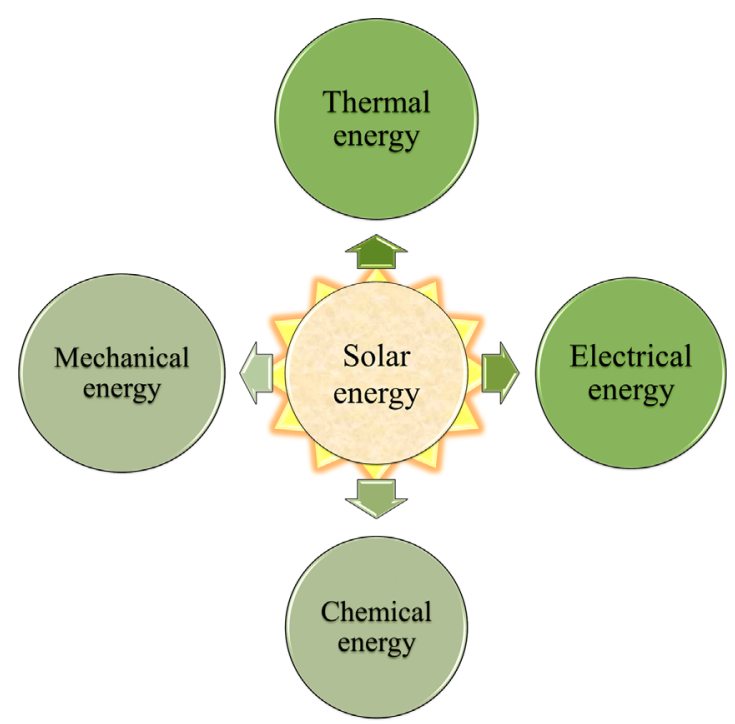

Fig. 1. Conversion of solar energy into other forms of energy.
This paper presents an overview of solar-thermal technology with an emphasis on methods adopted for enhancement of its performance. It also covers the description of different types of solar collectors to facilitate the systematic understanding of solar thermal technology and the novel modifications realized in each category of solar collectors have been highlighted to promote the use of solar energy in routine activities.

\section{Solar collectors}

Solar collector is a device that collects thermal energy of solar insolation by absorbing them. The thermal energy thus stored is carried away by a flowing fluid and utilized for some specific purposes. Fig. 2 shows the classification of solar collectors. The solar collectors are broadly classified as non-tracking and tracking collectors. The non-tracking collectors are kept at rest and also known as fixed or stationary collectors, whereas tracking collectors are designed to track the movement of sun so that the incoming solar radiations always fall perpendicular to them. The tracking solar collectors are further classified as one axis tracking and two axes tracking collectors. Non-tracking collectors are categorized as flat plate, evacuated tube and compound parabolic collectors. Parabolic trough collector, cylindrical trough collector, and linear Fresnel reflector fall under the category of single axis tracking systems, whereas central tower receiver, parabolic dish reflector, and circular Fresnel lens belong to dual axes tracking systems.

The collector that uses water as working fluid is termed as solar water heater $(\mathrm{SWH})$, whereas the collector utilizing air as working fluid is called solar air heater (SAH). A solar water heating (SWH) system comprises of the solar collector as well as the storage tank. The solar water heating systems are further classified as passive SWH systems (do not require external pumping agency and the flow takes place due to thermo-syphonic action) and active SWH systems (require pumping agency to circulate fluid through them). An integrated collector storage system (ICS) has both the collector and storage tank as single unit. Tang et al. $[3,4]$ investigated effects of temperature of water in the storage tank, structural and performance parameters of a thermosyphon on domestic SWH at clear nights. It was suggested that vertical cylindrical tank instead of horizontal cylindrical tank should be used for freeze protection. It was also found that an absorber with solar selective coating prevents freezing at clear nights too.

Hossain et al. [5] reviewed on SWH collector and thermal energy performance of circulating pipe, and summarized the findings about the thermal performance of the flat plate, concentrating, and other collectors of solar water heater with a mantle heat exchanger. They proposed an energy equation, which included a heat exchanger penalty factor. Shukla et al. [6] presented a review on the recent progress made in SWH technology. It was reported that the heat pump-based SWH could be a potential water heating system in the regions where solar energy is sparse. The performance of such systems was found to be influenced by the type of refrigerant employed. Shukla et al. [7] made a thorough survey on the use of phase change material (PCM) in solar water heating systems or heaters (SWHs). It was concluded that only preliminary designs of PCM-based SWHs were available. An inbuilt thermal storage could be an alternative to the present day solar water heating system. Ogueke et al. [8] reviewed solar water heating systems for domestic as well as industrial applications. It was concluded that despite their higher efficiency, active SWHs were not as popular as passive SWHs. Jaisankar et al. [9] surveyed on various heat transfer enhancement techniques for increasing the thermal efficiency of SWH. They suggested that an extensive research is required on parallel flow solar collector, the shape of 
Table 1

Few important reviews on solar thermal systems.

\begin{tabular}{|c|c|c|}
\hline Author(s) (year) & System & Findings \\
\hline Kalogirou (2004) [1] & Solar thermal collectors & $\begin{array}{l}\text { - Feasibility of solar thermal collectors in a number of areas emphasized. } \\
\text { - Optical, thermal and thermodynamic analyses are presented. }\end{array}$ \\
\hline Shukla et al. (2009) [7] & Solar water heaters & $\begin{array}{l}\text { - A phase change material with high latent heat and with large surface area for heat transfer can increase thermal } \\
\text { performance significantly. }\end{array}$ \\
\hline \multirow[t]{2}{*}{ Ogueke et al. (2009) [8] } & $\begin{array}{l}\text { Solar water heating } \\
\text { system }\end{array}$ & - Active SWH system is more efficient than the passive SWH system. \\
\hline & & - ICS has a lower efficiency than an ordinary passive SWH system. \\
\hline $\begin{array}{l}\text { Jaisankar et al. (2011) } \\
\text { [9] }\end{array}$ & Solar water heaters & $\begin{array}{l}\text { - The performance of parallel flow solar collectors is better than that of series flow collector. Research in parallel } \\
\text { flow collector is limited. }\end{array}$ \\
\hline Barlev et al. (2011) [2] & Concentrated collectors & - Presented the innovations and advancements in concentrated solar power technology. \\
\hline $\begin{array}{l}\text { Kumar and Rosen } \\
\text { (2011) [17] }\end{array}$ & $\begin{array}{l}\text { Photovoltaic-thermal } \\
\text { collectors }\end{array}$ & $\begin{array}{l}\text { - The overall efficiency of PV/T collectors is higher than the sum of individual efficiencies of photovoltaic and } \\
\text { thermal collectors. }\end{array}$ \\
\hline $\begin{array}{l}\text { Ibrahim et al. (2011) } \\
\text { [18] }\end{array}$ & $\begin{array}{l}\text { Photovoltaic-thermal } \\
\text { collectors }\end{array}$ & - Emphasized the need of improving PV efficiency and its integration with building components. \\
\hline Hossain et al. (2011) [5] & Solar water heaters & - SWH with a siphon system achieves $18 \%$ higher efficiency than that of a conventional system. \\
\hline $\begin{array}{l}\text { Chamoli et al. (2012) } \\
\text { [16] }\end{array}$ & $\begin{array}{l}\text { Double-pass solar air } \\
\text { heater }\end{array}$ & $\begin{array}{l}\text { - No study reported on artificially roughened double pass solar air heater. } \\
\text { - Maximum efficiency is obtained if the channel depth and mass flow rate are same in both the upper and } \\
\text { lower ducts. }\end{array}$ \\
\hline Tyagi et al. (2012) [15] & Solar air heating system & - Energy storage systems are useful where the temperature difference between the day and night is high. \\
\hline Shukla et al. (2013) [6] & $\begin{array}{l}\text { Solar water heating } \\
\text { system }\end{array}$ & - Technical advancements in SWH systems. \\
\hline & & - Polymer flat plate collectors are replacing metal flat plate collectors. \\
\hline $\begin{array}{l}\text { Ho and Iverson (2014) } \\
\text { [35] }\end{array}$ & $\begin{array}{l}\text { Solar concentrating } \\
\text { systems }\end{array}$ & $\begin{array}{l}\text { - Plugging due to solidifications and more efficient particle/fluid heat exchangers are challenges to liquid and solid } \\
\text { receivers, respectively. }\end{array}$ \\
\hline
\end{tabular}

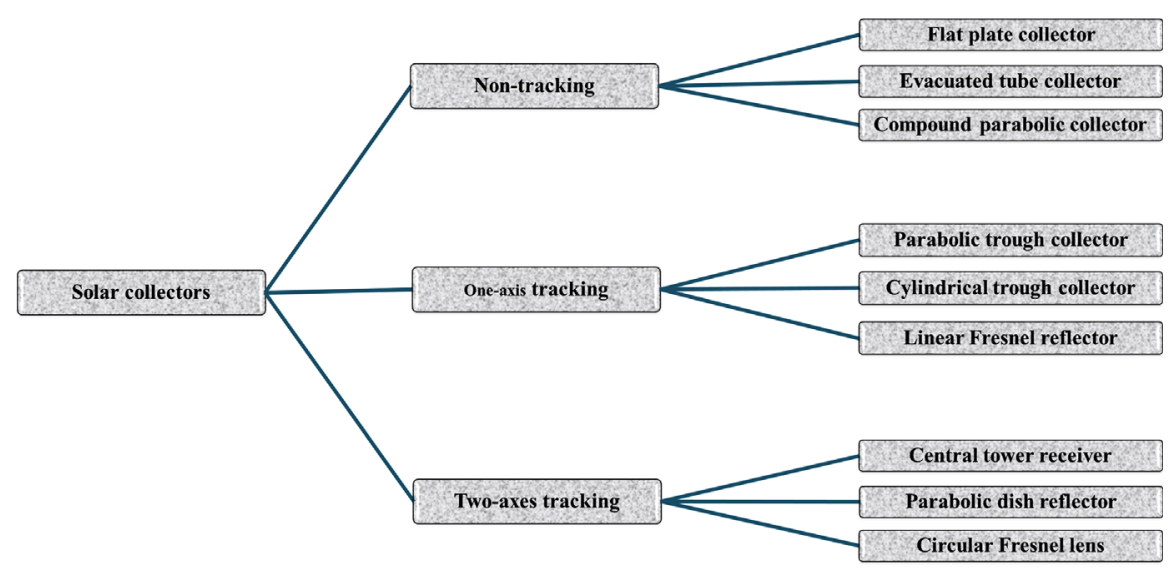

Fig. 2. Classification of solar collectors.

glass cover, and movement of ambience air over its surface for the optimization of thermal performance of SWH.

The solar air heaters (SAHs), on the other hand, are classified as single pass and double-pass SAHs. In single pass SAH, the air passes through the heater once, whereas the air passes through the heater twice in double pass SAH. It flows over the absorber plate in the forward pass, and below the absorber plate in the return pass. The efficiency of a double pass SAH is higher than the 
single pass heaters. The solar water heaters are more efficient than the solar air heaters because of higher convective heat transfer coefficient between the fluid and the absorber plate. Some of the relevant studies on solar air heaters and their performance enhancement have been mentioned in Section 3.1.

\subsection{Non-tracking or stationary collectors}

These collectors remain stationary irrespective of position of the sun in the sky. However, they are installed at a particular tilt and orientation angles, whose magnitudes are dependent upon the geographical location (latitude), to maximize the harnessing of solar radiation, as shown in Fig. 3.

\subsubsection{Flat plate collectors}

A flat plate collector, shown in Fig. 4, consists of a transparent glass cover, an absorber plate with a parallel back plate. Depending upon the type of fluid, that is air or water, the flow passage is designed. For air as a working fluid, the gap between the absorber plate and back plate is made passage for the flow of fluid. When water is used as a working fluid, the copper tubes brazed on the absorber plate are made flow passages. In this case, the back plate is not required. The collector is insulated from the sides as well as from the bottom to further minimize the heat loss. A glass cover at the top helps in reducing the convective as well as radiative heat loss from the absorber plate to the outside air. During prolonged usage, the dust settles on the glass cover of the collectors that affects their performance adversely. Ghazi et al. [10] summarized the effect of dust settlement and various cleaning mechanisms deployed in different global zones. Cleaning is usually done by one of the following methods: (a) washing by water jet, (b) blowing by compressed air jet, (c) manual tilting of the collector, (d) use of automatic wiper, (e) use of super-hydrophilic nano-film, and (f) use of electrostatic dust removal prevention method (counter balancing the electric charge available in the dust).

The choice of collector dimensions (length and width) is significant and is dependent upon the type of application. Yeh and Lin

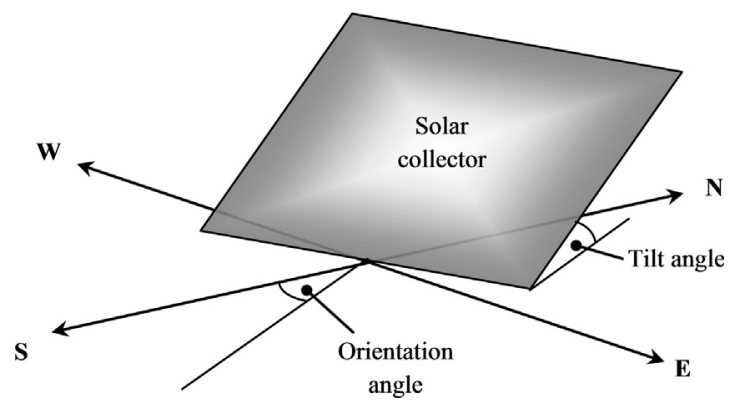

Fig. 3. Orientation of stationary collectors.

a

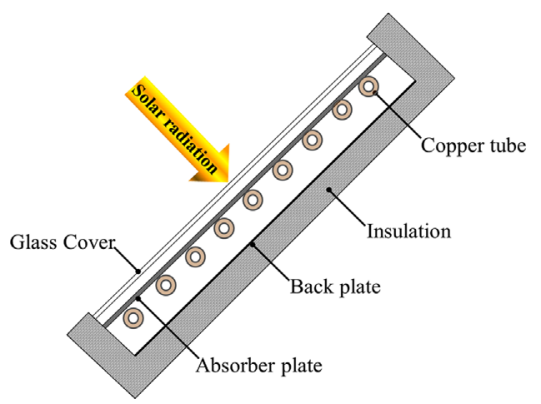

[11] carried out analytical and experimental studies to investigate the effect of aspect ratio (length/width) on the efficiency of flat plate collector. It was found that the collector efficiency increases with increase in collector aspect ratio for constant collector area.

Few novel approaches in flat plate collectors have been reported in the literature. Ammari and Nimir [12] developed a solar water heater replacing metal absorber plate with tar covering water tubes. They found that the tar-based collector performed better than the conventional flat plate collector in the late afternoon hours. Alvarez et al. [13] developed a flat plate collector for solar air heater in which absorber plate was replaced by an array of recyclable aluminum cans painted black. They found that maximum thermal efficiency achieved was $74 \%$. The advantages offered by this novel collector are recycling of waste cans, being cheaper, and providing a cleaner environment.

\subsubsection{Hybrid photovoltaic/thermal (PV/T) collectors}

A new generation of solar collectors, known as hybrid PV/T solar systems, has recently been developed. Such systems serve both the purposes (a) direct electricity generation using photovoltaic cells and (b) solar thermal conversion. One such system is shown in Fig. 5; it consists of PV cells encapsulated on one side of an absorber plate, whereas there is provision for the flow of fluid to be heated on the other side of the absorber plate. If the fluid is water, the copper pipes are brazed on the other side. However, for air as working fluid, a channel is provided between the absorber plate and the back plate; an arrangement already discussed in the description of solar air heaters. It

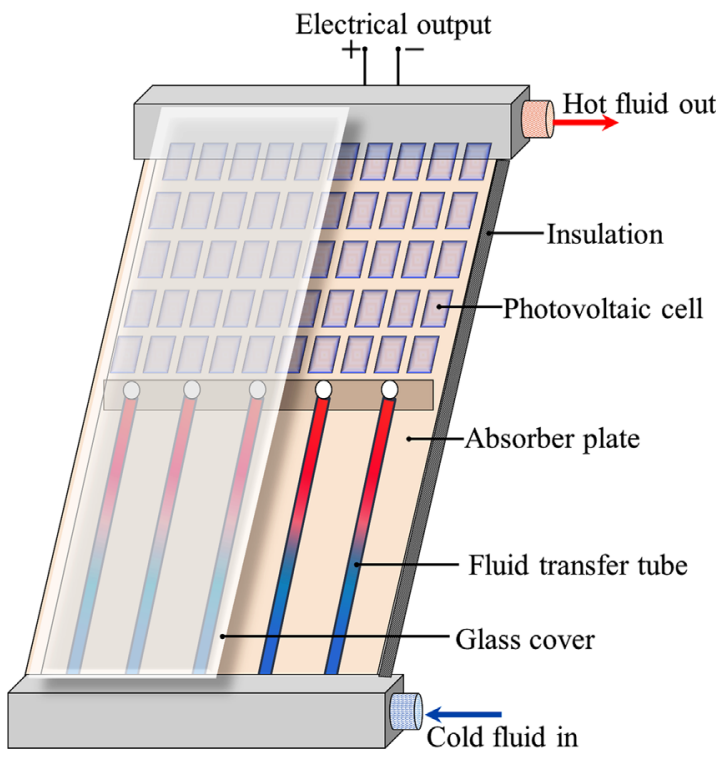

Fig. 5. Hybrid photovoltaic-thermal collector.

\section{b}

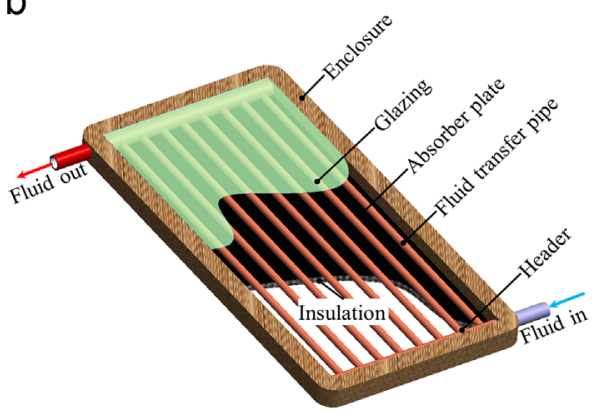

Fig. 4. Flat plate collector: (a) end view and (b) 3D view. 
should be noted that the efficiency of PV cells decreases at high temperatures. Hence, maintaining PV cells in a specific range of temperature by removing the heat from them through a working fluid will result in their higher efficiency, and the heat carried away by fluid may also be utilized. Such systems can be employed for simultaneous production of electricity and low temperature hot water for domestic purposes. Compared to PV systems, PV/T systems have much shorter economic payback period because of the integrated cooling arrangement of solar panel. Chow [14] carried out a meticulous review on hybrid PV/T collectors. It was mentioned that various configurations of $\mathrm{PV} / \mathrm{T}$ were possible by changing the type of working fluids or coolants (air or water), type of collectors (flat plate or concentrating), material of photovoltaic cell (monocrystalline, polycrystalline and amorphous silicon), number of glazing (single or double) and fluid flow (above absorber, below absorber or counter flow). It was also found that such collectors were in infancy stage and their commercial availability was very limited. Tyagi et al. [15] reviewed the research works on solar air heating systems and their performance for different applications. They concluded that flat plate air heater produced low temperature hot air suitable for drying agricultural products. They also suggested that hybrid photovoltaic/ thermal (PV/T) type solar air heaters were found suitable for forced convective air heating with electricity generation. In addition, the thermal energy storage solar heaters using phase change materials (PCMs) were found to fit for crop drying applications. Chamoli [16] carried out the extensive study of the research conducted on doublepass solar air heater with a focus on heat transfer enhancement, pressure drop and flow phenomenon. They observed that most of the studies carried out so far were primarily focused on double pass solar air heater integrated with porous media and extended surfaces. A good number of studies were also carried out with corrugated absorber. They suggested that there was a scope for investigations on double pass solar air heater having absorber plate artificially roughened on the both sides. Kumar and Rosen [17] critically reviewed photovoltaic-thermal solar collectors exclusively for air heating and suggested that $\mathrm{PV} / \mathrm{T}$ air heater might be a promising technology for space heating and drying applications. They reported that the hybrid $\mathrm{PV} / \mathrm{T}$ collectors are more efficient than each of the photovoltaic or solar thermal systems. However, the efforts should be made to improve its efficiency and design. Ibrahim et al. [18] summarized various types of $\mathrm{PV} / \mathrm{T}$ collector and its different designs along with their efficiency. Systematic comparison of different designs features of PV/T collector and their performance was also done. The highlight of their review was the presentation of the future prospects of $\mathrm{PV} / \mathrm{T}$ collectors in building integration. They suggested that PV/T system could be made more competitive by enhancing the efficiency of PV and by developing better ways to integrate it with structural components of buildings.

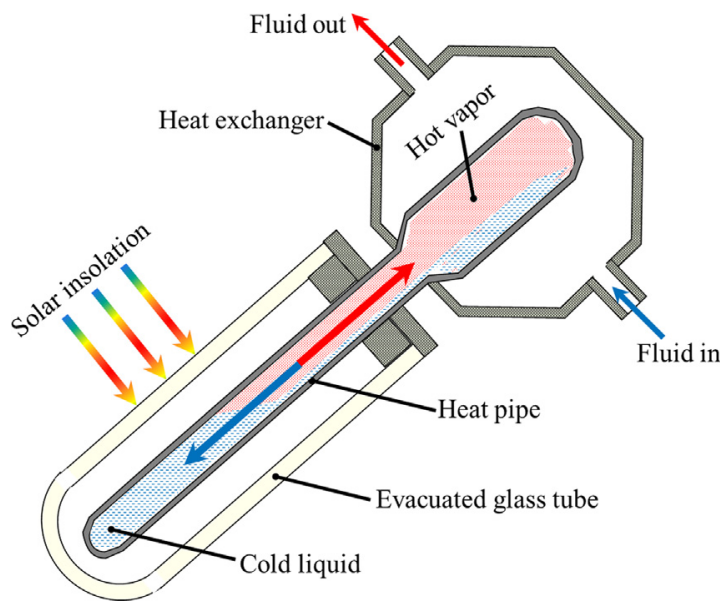

Fig. 6. Evacuated tube collector.
In the direction of enhancing the efficiency of PV/T system, Sardarabadi et al. [19] used cheap silica/water nanofluid and performed experimental investigation on it. After performing thermodynamic analysis, it was observed that silica/water nanofluid suspension substantially enhances the performance of a PV/T system both energetically and exergetically. However, the cost of stable nanofluids is a concern. Recently, Zafar and Dincer [20] proposed a novel combined PV/T-fuel cell system, which can be simultaneously used for the generation of electricity directly, heated air, purified water, and hydrogen. They even claimed that for largescale operation or for longer durations, the water output can even cater the drinking water needs for residential and commercial travel purposes. It will be exciting to witness the commercialization of such concepts; however, cost is a big hurdle in this regard.

\subsubsection{Evacuated tube collectors}

The evacuated tube collector (ETC) consists of a heat pipe kept inside a glass enclosure, as shown in Fig. 6. The heat pipe uses liquid like ethanol, methanol, water etc. to capture heat of solar insolation and this liquid transfers heat to some other working fluid while undergoing evaporation-condensation cycles. On receiving solar radiation, the liquid inside the heat pipe undergoes phase change and it is converted into vapor, which rises toward the upper part of the heat pipe due to buoyancy. The vapor condenses back to liquid after transferring heat to the working fluid in the heat exchanger section at the top. The liquid flows back to the bottom of heat pipe due to gravity, and the cycle continues. The glass enclosure is evacuated to minimize the heat loss due to convection and to prevent climatic degradation of its inner materials. Quite often, heat pipes are also evacuated to allow phase change of the inner liquid at low temperatures. Its efficiency is not significantly affected by change in incidence angle of sun's radiation. This feature of ETC provides flexibility to tube orientation from $25^{\circ}$ to $60^{\circ}$ at the time of installation.
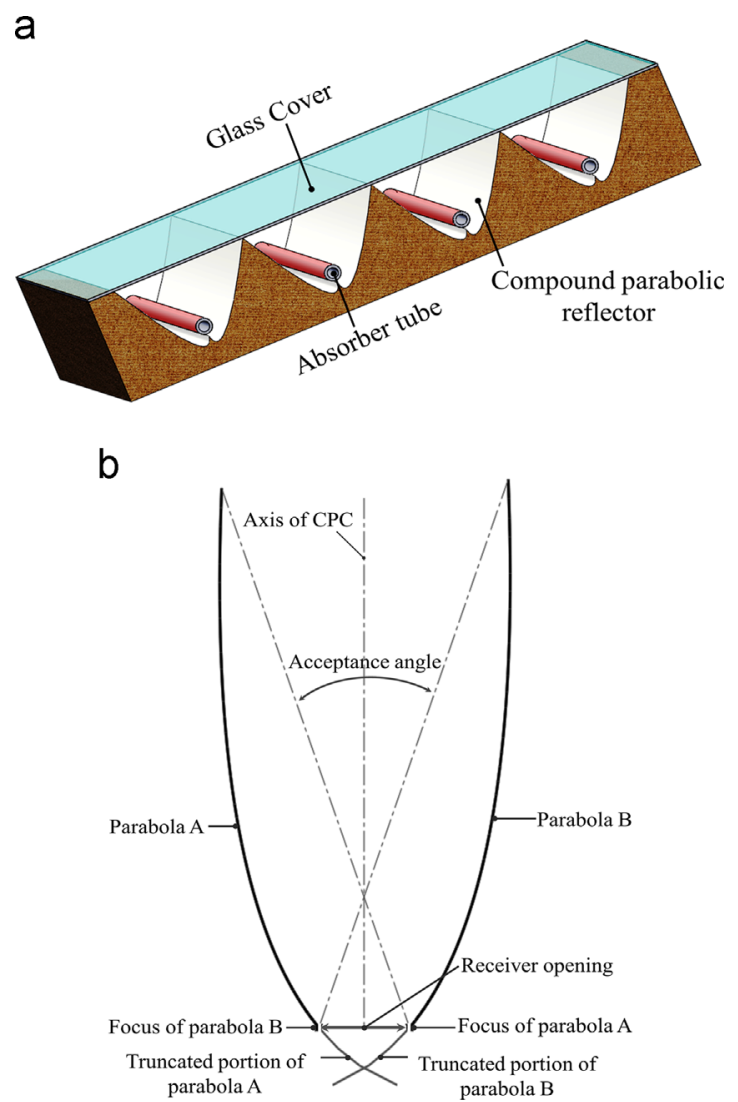

Fig. 7. Compound parabolic collector: (a) 3D view and (b) 2D schematic. 
Single tube ETCs are rarely used in practice. A number of evacuated tubes are integrated and connected to a common header to achieve high coolant temperatures. The two types of arrangements are commonly used for ETCs: H-type and T-type collectors. It should be noted that T-type collectors collect slightly more radiation compared to H-type collectors on an annual basis. Tang et al. [21] developed a mathematical model for calculating daily collectible radiation for given geometrical and structural parameters of ETC. They recommended that for latitudes greater than $30^{\circ}$, the tilt angle for T-type collector should be $10^{\circ}$ less than the site latitude, and the same should be $20^{\circ}$ less than the site latitude for H-type collector.

\subsubsection{Compound parabolic collectors}

The compound parabolic collector (CPC) consists of a glass cover, an absorber tube and two parabolic reflecting surfaces, as shown in Fig. 7(a). The two parabolic reflecting surfaces ' $A$ ' and ' $B$ ' have their focal points lying on each other, as shown in Fig. 7(b). The part of parabolic surfaces below focal points does not contribute toward the convergence of solar radiations and, hence, the parts below the focal points are truncated. The absorber tube is placed at the mid plane between the two focal points. If the angle of incidence is less than half of the acceptance angle, the solar radiation will pass through the receiver opening. If the angle of incidence is greater than half of the acceptance angle, the solar radiation will ultimately be reflected back to the ambience through the upper opening (aperture). The orientation of the parabolic reflectors should be such that the sun's position or angle of incidence has no effect on the performance of the collector. Thus, aligning the CPC's receiver or absorber tube along east-west line eliminates the need of tracking throughout the day.

Nalwanga et al. [22] extended the use of CPC for water disinfection using solar radiations. They fitted $25 \mathrm{~L}$ borosilicate glass filled with water infected by Escherichia coli bacteria on the CPC tube. The experimental results showed a complete bacterial disinfection with strong dependence on exposure time and weather conditions. It was suggested that СРC could be deployed for drinking water treatment at household as well as at institutional level.

Guiqiang et al. [23] designed a novel lens-walled CPC with air gap. In this design, there is an air gap between the lens and the reflector, which causes the total internal reflection and minimizes the optical losses due to specular reflection. Consequently, the optical efficiency is significantly improved.

\subsection{Tracking collectors}

The position of sun needs to be tracked for the maximum utilization of the incoming solar radiation. The intensity of solar radiation varies during the day as well as with seasons. The tracking collectors can be divided into two categories: one axis tracking and two-axes tracking collectors.

Mousazadeh et al. [24] reviewed the works on tracking systems. It was mentioned that the use of a tracker in a solar collector can enhance the collected energy in the range of $10-100 \%$ depending upon the time and geographical location of the site. The use of tracker increases the power consumption and it was recommended not to use trackers in low capacity solar collectors.

Ren et al. [25] discussed various methods used in alignment of collectors for maximum collectability of solar insolation. These methods are broadly classified into two categories: mechanical alignment, and optical alignment methods. Mechanical methods include the use of inclinometers, the gauge block method, and the linear displacement transducer method and are applicable for aligning heliostats having several flat mirrors. However, it was suggested that mechanical methods are not suitable for large scale heliostat

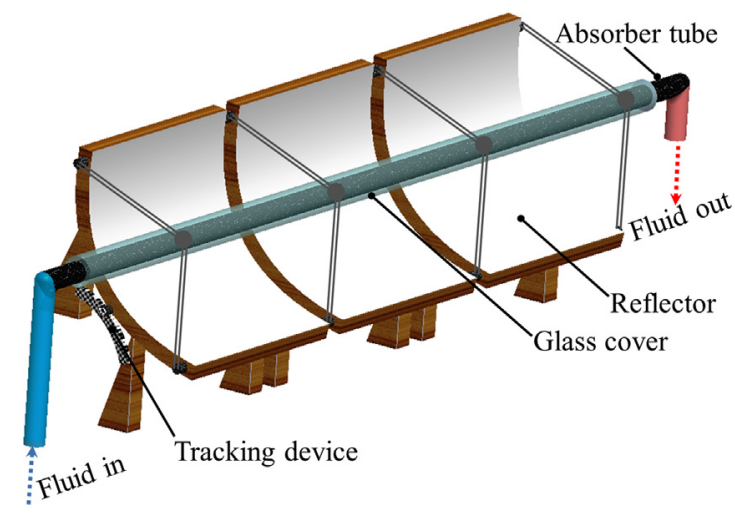

Fig. 8. Parabolic trough collector.

fields used in central tower receiver systems. Optical alignment methods, on the other hand, include photogrammetry, laser method, theoretical image overlay method, camera look-back method, fringe reflection method etc. These methods were found to be more accurate than their mechanical counterparts but are expensive.

\subsubsection{One axis tracking collectors}

The collectors in this category are oriented along north-south line and the sun's position is tracked from east to west throughout the day. This category of collectors mainly comprises of parabolic trough collector, cylindrical trough collector and linear Fresnel reflector.

Kalogirou [26] developed one axis tracking system for collectors under this category. The system comprised of three light dependent resistors (LDRs), each serving a definite function. First LDR was used for collector orientation toward the sun, second LDR detected the presence of cloud, and the third LDR was put for sensing whether it is day or night time. The signals of all these LDRs were fed to a DC motor that rotated the collector through a gearbox.

2.2.1.1. Parabolic trough collectors. The parabolic trough collector consists of a parabolic reflecting surface with an absorber tube placed along its focal line. The position of sun is tracked for normal incidence of solar radiations at any instant of time (Fig. 8). Garcia et al. [27] presented an overview of the existing parabolic-trough collectors and their prototypes under development. The study summarized the use of such collectors for energizing steam power cycles for electricity generation as the working fluid temperature can be of the order of $400{ }^{\circ} \mathrm{C}$. Price et al. [28] claimed on the basis of thorough review on parabolic trough collector that solar power generation using these collectors was the most reliable and robust technology. However, they emphasized that there was a need to bring down the cost.

The parabolic trough collector is usually employed for largescale power generation. However, it can be also used for smallscale direct steam generation. The direct generation of steam using a parabolic trough collector increases overall pressure drop, as there is an additional acceleration pressure drop. Lobon and Valenzuela [29] developed a model to predict the thermohydraulic performance of the parabolic trough collector in which saturated steam was generated directly. The numerical results showed that the inlet pressure of working fluid (water) was the deciding factor for the feasibility of such systems. If the inlet pressure was increased from $1 \mathrm{MPa}$ to $2 \mathrm{MPa}$, the overall pressure drop across the absorber was significantly reduced for a given outlet pressure and temperature conditions. Based on this model, it was claimed that small parabolic trough collectors could be used for direct steam generation with an affordable pumping power. 
a

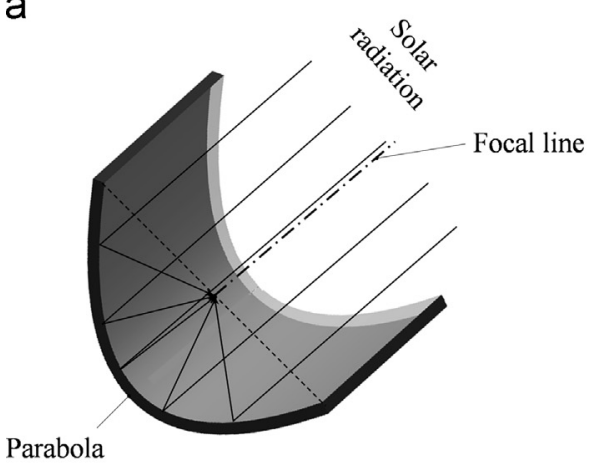

b

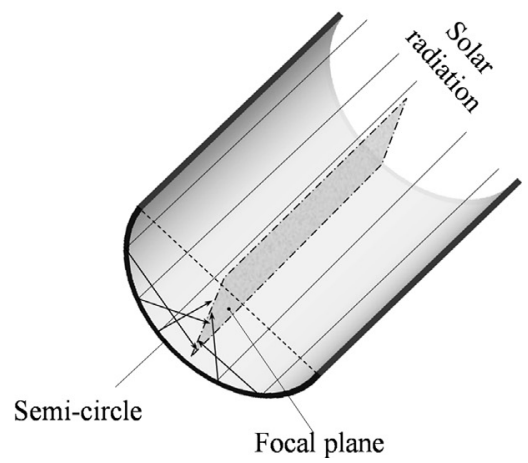

Fig. 9. Difference between (a) parabolic and (b) cylindrical trough collectors.
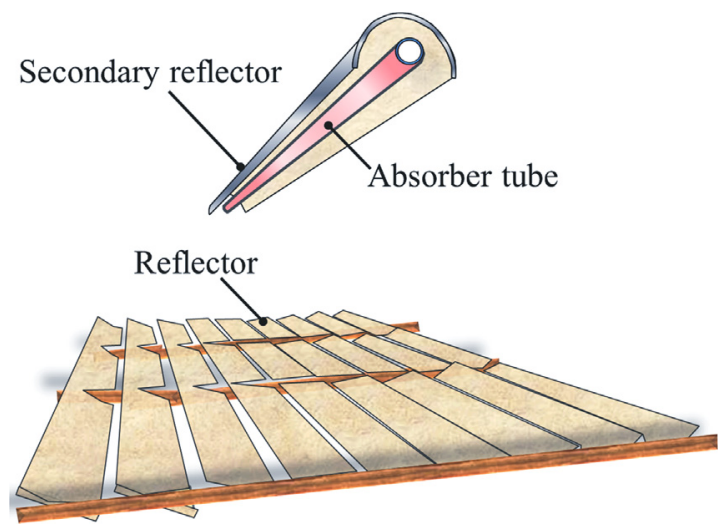

Fig. 10. Linear Fresnel reflector.

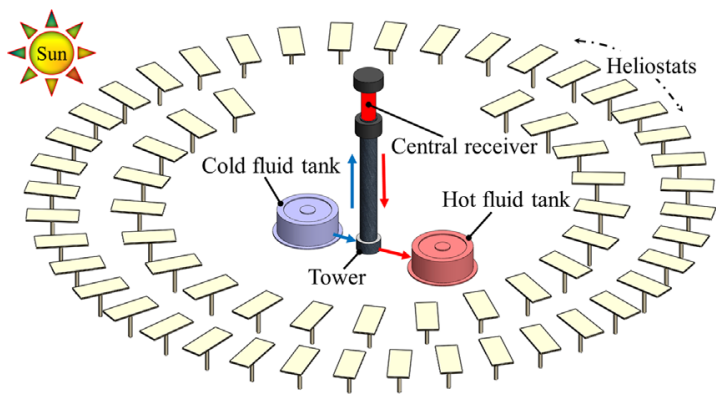

Fig. 11. Central tower receiver.

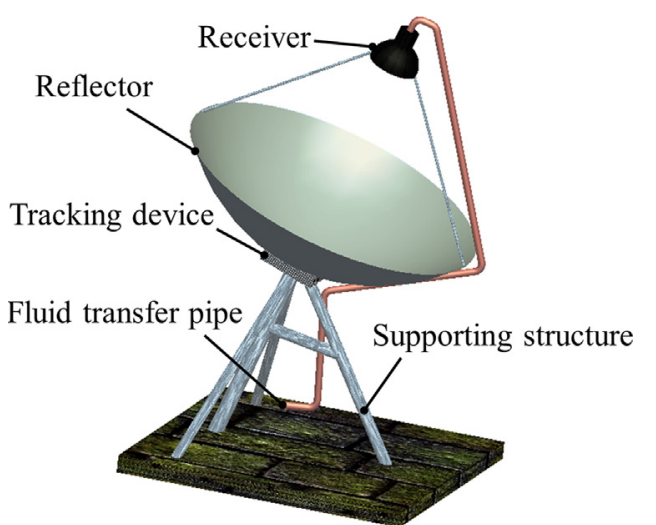

Fig. 12. Parabolic dish reflector.

Arasu and Sornakumar [30] used hand lay-up method for manufacturing low cost parabolic trough collector using reinforced fiber glass. The collector conformed to ASHRAE standard 93 [31] and its thermal efficiency was found to be nearly $70 \%$. Due to its low cost, the authors recommended the methodology for batch production for all collector sizes.

2.2.1.2. Cylindrical trough collectors. The cylindrical trough collectors are similar to parabolic collector with a difference that the rays converged in a focal plane rather than the focal line, as shown in Fig. 9. These types of collectors are rarely in practice.

2.2.1.3. Linear Fresnel reflectors. The linear Fresnel reflectors, shown in Fig. 10, are generally flat mirrors used to concentrate the solar radiation on absorber tubes like in parabolic trough collectors. Due to lower concentration factor than that of parabolic trough collector, the lower operating temperatures are normally achieved in the working fluid. Thus, such plants operate at a lower efficiency. Barlev et al. [2] studied the innovative work in concentrated solar power extensively and found that linear Fresnel reflector is the cheapest and reliable for an operational temperature up to $300{ }^{\circ} \mathrm{C}$.

Focus Fresnel reflectors are used as an alternative to conventional tracking of trough collectors discussed in previous sections. Mills et al. [32] proposed a compact linear Fresnel reflector system in which there was an array of multiple receivers mounted on separate towers. The proposed design was expected to produce $95 \mathrm{MW}$ of thermal energy and could be used as a preheater in a conventional thermal power plant.

\subsubsection{Two axes tracking collectors}

Two axes tracking systems have two axes of rotation mutually perpendicular to each other. Primary axis is one which is fixed with respect to the ground, whereas the secondary axis is positioned with respect to the primary axis. The collectors are usually oriented parallel to the secondary axis. The two axes trackers are advantageous as they allow better utilization of solar radiations due to their capability to track the sun both horizontally and vertically.

Sharan and Prateek [33] developed a low torque microprocessor based two-axes tracking system. The design was based on the solution of dynamic equations of planetary motion. They employed a stepper motor controlled by microprocessor. Use of microprocessor lowered the cost of tracking system compared to sensor-based trackers. The system was tested for seasonal variations and the performance was found to be accurate.

2.2.2.1. Central tower receivers. This type of arrangement is employed in large-scale installations meant for power generation. The system has a central tower surrounded by a large number of heliostats having individual two axes tracking systems, as shown in Fig. 11. The solar energy is concentrated by the heliostat field on a 
receiver mounted at the top of central tower. Water, molten salt, and pressurized air are the typical working fluids for this type of plants.

Barlev et al. [2] reported that heliostat field collectors were gaining popularity rapidly as they could be used to generate very high temperatures (up to $2000{ }^{\circ} \mathrm{C}$ ). Behar et al. [34] summarized the studies pertaining to the major components of central receiver system (CRS). They suggested that CRS has the potential to replace conventional thermal power plants. Ho and Iverson [35] exclusively concentrated upon the studies of high-temperature central receiver designs for concentrating solar power. They discussed the classification of receiver designs and key challenges associated with each of them. They reported a revival of solid-particle approach in receivers design due to promising corrosion and material interaction phenomenon. Nevertheless, it too has some technical challenges associated like particle conveyance, attrition, transport etc.

2.2.2.2. Parabolic dish reflectors. The parabolic dish collector, shown in Fig. 12, has a parabolic dish fitted with two-axes tracking system. The rays are concentrated at a point where receiver is placed. Inside the receiver, a heat exchanger is provided which allows the heat to be transferred to the working fluid. The arrangement looks like a satellite dish antenna. Eswaramoorthy and Shanmugam [36] developed a low-cost parabolic dish collector using a scrap satellite dish antenna and studied thermal performance of the collector. They found that for solar radiation intensity of $950 \mathrm{~W} /$ $\mathrm{m}^{2}$, the stagnation temperature inside the receiver was $450{ }^{\circ} \mathrm{C}$. The receiver was made up of aluminum solar cooker whose thermal and overall efficiencies were found to be $60 \%$ and $40 \%$, respectively.

Commercially available large parabolic dish collectors are costly due to the requirement of very high precision in its manufacturing, and difficulties in their transportation. Li and Dubowsky [37] presented a novel concept for designing and fabricating large parabolic dish mirrors. They recommended the use of thin and flat metal petals having high reflectivity assembled together with the help of cables to form a parabola. The proposed design has good prospects to provide an alternative for expensive commercially available large dish collectors with an acceptable precision.

2.2.2.3. Circular Fresnel lens. A conventional convex lens is used to concentrate light at a point. Extremely high temperatures are achieved at the point where rays are concentrated. This property of a lens is exploited in this type of collectors. The circular Fresnel lens differs slightly from conventional lens with planar surface merged in between the convex side, as shown in Fig. 13. This arrangement allows capturing of more oblique light from a light source. Also, instead of a point, the rays are converged to a small area using circular Fresnel lens. It is light in weight even with large aperture as they are capable of being manufactured in the form of very thin flat sheet. Fresnel lens is generally used in lighthouse to be visible over greater distances for the purpose of navigation.

Nia et al. [38] presented a design in which Fresnel lens was used to generate thermal gradient across the absorber of thermoelectric (TE) module. From Peltier effect, the electromotive force is
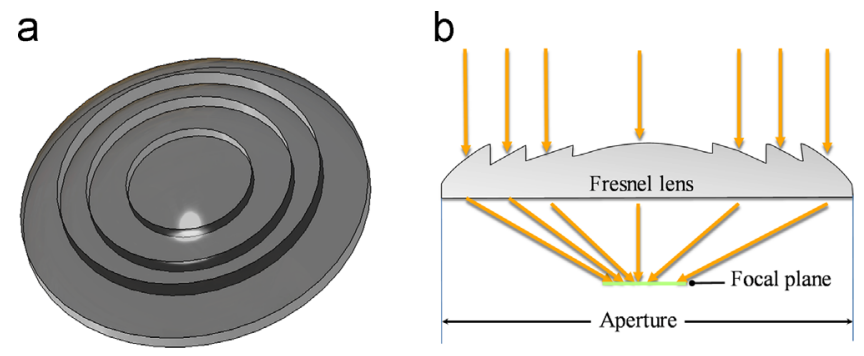

Fig. 13. Circular Fresnel Lens: (a) 3D view and (b) ray diagram. generated and electricity is produced. For solar intensity of $705.9 \mathrm{~W} / \mathrm{m}^{2}$, an output power of approximately $1 \mathrm{~W}$ with $51.33 \%$ efficiency was obtained. An array of Fresnel lenses was recommended for TE module with the use of intermediate fluid.

\section{Performance enhancement of solar collector}

The efficient removal of heat from the solar collectors is the prime objective of any solar thermal system. The performance of a solar collector depends upon how much a working fluid heat carries away the heat from the collector. This section is dedicated to the techniques used to enhance the performance of the collectors discussed in the previous section. The literature on performance enhancement of solar collectors can be classified into three main groups: (a) increasing the heat transfer coefficient between the absorber plate/tube and the working fluid (i.e., artificially roughened absorber plates/tubes), (b) using special type of coatings on the absorber (i.e., solar selective coatings), and (c) increasing the thermal conductivity of the working fluid using nanoparticles (i.e., nanofluids). These methods and the relevant studies have been described in the subsequent sections.

\subsection{Geometrical modifications}

In principle, the heat transfer between a fluid and a solid surface is increased by increasing the contact area (i.e. extended surfaces) and by creating turbulence, which promote mixing between the various fluid layers. The nature of working fluids actually governs the type of geometrical modification to be made in the absorber assembly. If the working fluid is air or gas, which has very low convective heat transfer coefficient, the extended surfaces/fins/corrugations are provided on the absorber plate. For water or liquid as the working fluid, twisted tapes/perforated tapes/wire coils, inserts/ baffle plates, and internally finned tubes are provided to generate turbulence, which eventually increase heat transfer coefficient. However, the use of surface modifications and turbulence promoters results in an increased pressure drop, which ultimately increases the consumption of pumping power. Any heat transfer enhancement technique is acceptable only if the gain in heat transfer rate is more than the increase in pumping power. Different geometrical modifications are, thus, employed for air and water heaters.

Volumes of work are available for heat transfer enhancements in solar air heaters and solar water heaters. Some of the studies pertaining to air heaters are summarized in Table 2. Varun et al. [39] summarized the studies on the use of various roughness geometries and their other quantitative parameters. They discussed the flow patterns of each shape along with Nusselt number and friction factor correlations. Bhagoria et al. [40] experimentally investigated transverse wedge shaped rib having relative height in range of $0.015-0.033$ and varied the wedge angle from $8^{\circ}$ to $15^{\circ}$. The ribs yielded Nusselt number up to 2.4 times and the friction factor increased up to 5.3 times in comparison to that of smooth duct. The maximum heat transfer takes place for a relative roughness pitch of about 7.57 and at a wedge angle of $10^{\circ}$. The correlations developed for Nusselt number and friction factor are within the error limits of $\pm 15 \%$ and $\pm 12 \%$, respectively. Jaurker et al. [41] performed experimental investigation on heat transfer and friction characteristics of a solar air heater using rib-grooved artificial roughness to find optimized conditions for its performance. It is observed that rib-grooved arrangement provides the best thermo-hydraulic performance and yields Nusselt number up to 2.7 times, while the friction factor rises up to 3.6 times. The optimized groove position to pitch ratio is determined to be 0.4 , and the correlations developed for the Nusselt number, and the friction factor are found to be within deviations of $2.73 \%$ and $3.16 \%$, respectively. Lanjewar et al. 


\begin{tabular}{ll}
\hline $\begin{array}{l}\text { Author(s) } \\
\text { (Year) }\end{array}$ & Types of roughness \\
\cline { 2 - 3 } & Shape Configuration \\
\hline $\begin{array}{c}\text { Bhagoria et al. Wedge } \\
(2002) \text { [40] }\end{array}$ shaped rib \\
Jaurker et al. Rib-grooved
\end{tabular}

(2006) [41]

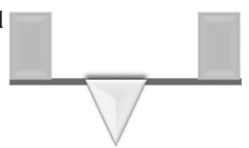

$e / D=0.0181-0.0363$

$p / e=4.5-10.0$

$\mathrm{g} / \mathrm{p}=0.3-0.7$

$N u=0.002062 \operatorname{Re}^{0.936}(e / D)^{0.349}(p / e)^{3.318}$

$\times \exp \left[-0.868\{\ln (p / e)\}^{2}\right](g / p)^{1.10}$

$\times \exp \left[2.486\{\ln (g / p)\}^{2}+1.406\{\ln (g / p)\}^{3}\right]$

Heat transfer coefficients

: $3000-18,000$

p/e $=60.17 \phi^{1.0264}$

$<p / e<12.12$

$8-15$

$$
W / H=5
$$

$N u_{r}=1.89 \times 10^{-4}(\operatorname{Re})^{1.21}\left(e / D_{h}\right)^{0.426}(p / e)^{2.94}\left[\exp \left(-0.71(\ln (p / e))^{2}\right)\right]$

$(\phi / 10)^{-0.018}\left[\exp \left(-1.50(\ln (\phi / 10))^{2}\right)\right]$

Findings

(1)

(n)

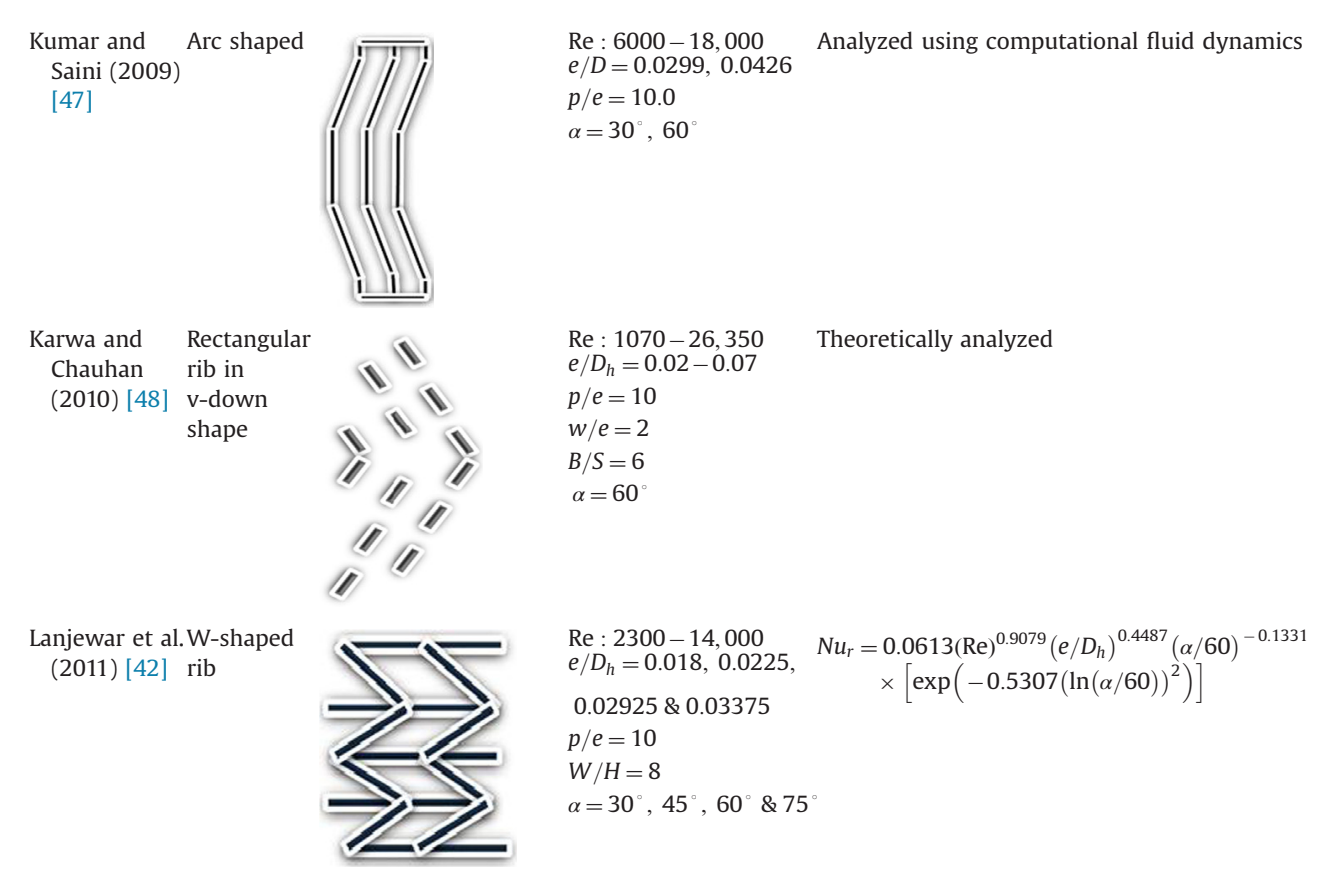

transfer occurs for

a relative

roughness pitch of

about 7.57 and at a

wedge angle of 10

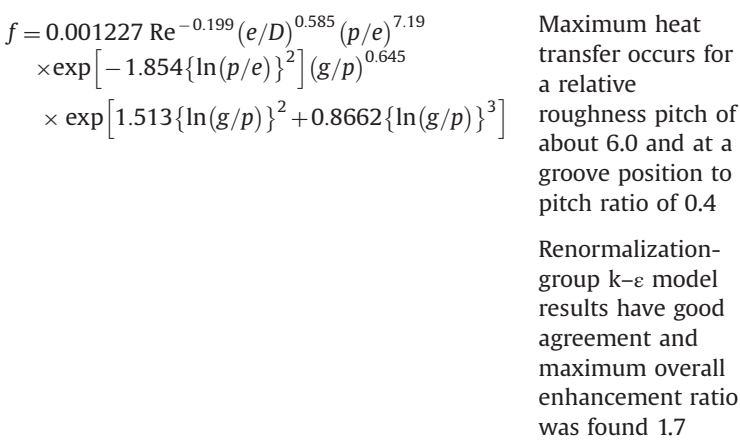

about 6.0 and at a

groove position to pitch ratio of 0.4

Renormalizationgroup $\mathrm{k}-\varepsilon$ model results have good agreement and maximum overall enhancement ratio was found 1.7

Roughened ducts are suitable only when mass flow rate is low; at high flow rate effective efficiency is same for both roughened and smooth duct

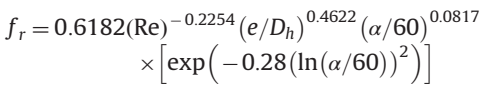

Maximum

enhancement of $\mathrm{Nu}$ and $f$ due to artificial roughness is 2.36 and 2.01 times, respectively, for $\alpha=60^{\circ}$ 


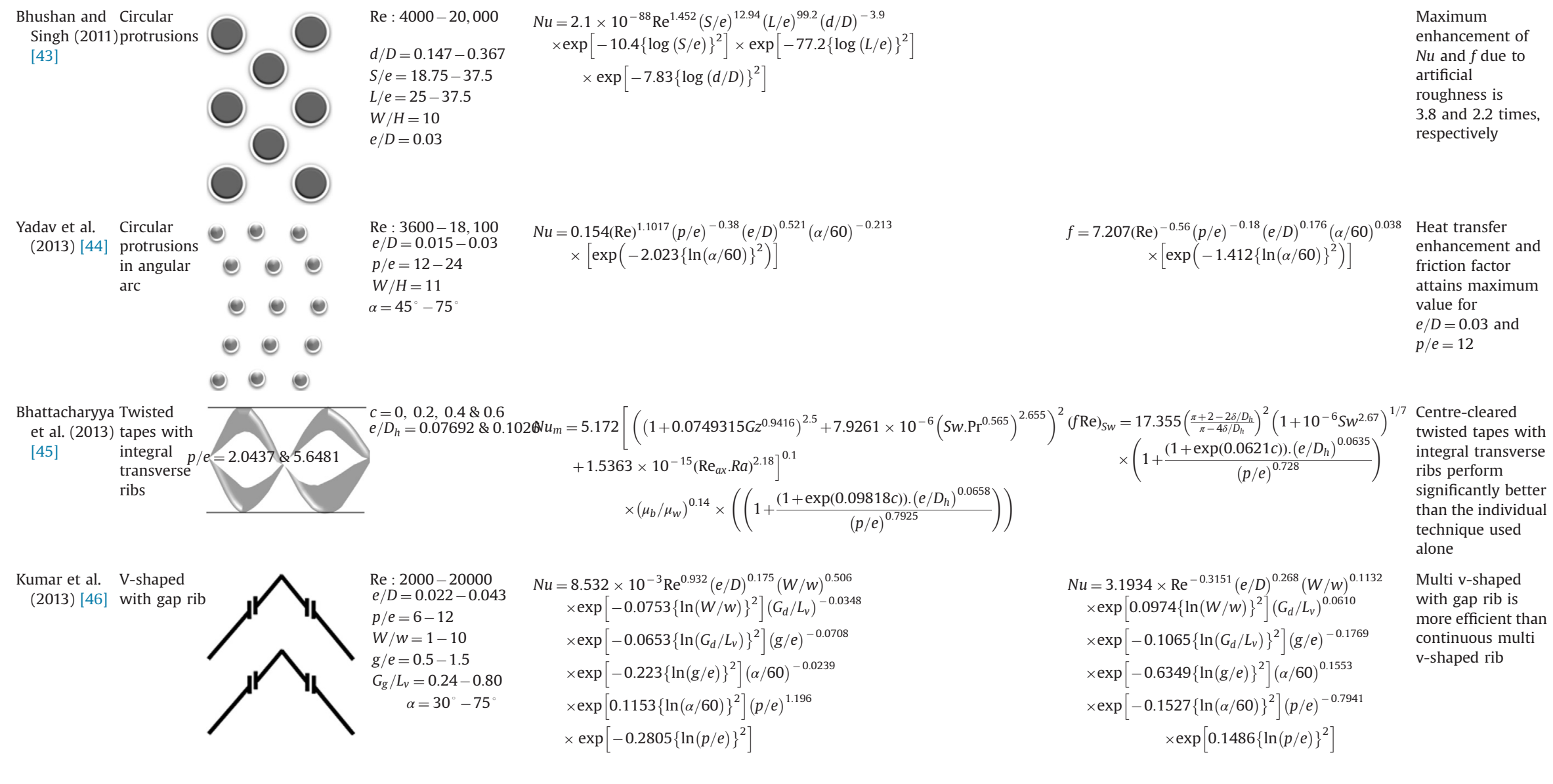

Re : $4000-20,000 \quad N u=2.1 \times 10^{-88} \operatorname{Re}^{1.452}(S / e)^{12.94}(L / e)^{99.2}(d / D)^{-3.9}$

$W / H=10$

Re : $3600-18,100$

$0.154(\operatorname{Re})^{1.1017}(p / e)^{-0.38}(e / D)^{0.521}(\alpha / 60)^{-0.21}$

$\times\left[\exp \left(-2.023\{\ln (\alpha / 60)\}^{2}\right)\right]$
$f=7.207(\operatorname{Re})^{-0.56}(p / e)^{-0.18}(e / D)^{0.176}(\alpha / 60)^{0.038} \quad$ Heat transfer $\times\left[\exp \left(-1.412\{\ln (\alpha / 60)\}^{2}\right)\right] \quad \begin{aligned} & \text { enhancement } \\ & \text { friction factor }\end{aligned}$

attains maximum

value for

$p / e=12$

twisted tapes with

ribs perform

ignificantly better

han the individu

more efficient than

continuous multi

$\times \exp \left[-0.1065\left\{\ln \left(G_{d} / L_{v}\right)\right\}^{2}\right](g / e)^{-0.1769}$

$\times \exp \left[-0.6349\{\ln (g / e)\}^{2}\right](\alpha / 60)^{0.155}$

$\times \exp \left[0.1486\{\ln (p / e)\}^{2}\right]$ 
[42] used the W-shaped rib roughness inside the rectangular duct of a solar air heater and investigated the heat transfer along with friction factor for different angles of attack of flow in the range of $30-75^{\circ}$. It is observed that ribs in $\mathrm{W}$-configuration are shorter than ribs of V-shaped configuration for same width of plate. The boundary layer along relatively shorter W-ribs is thinner than boundary layer along V-shape ribs, giving better thermo-hydraulic performance for W-ribs than V-ribs. The best thermo-hydraulic performance and the maximum enhancement of Nusselt number and the friction factor are achieved at the angle of attack of $60^{\circ}$. It is also seen that rate of increase of Nusselt number with increasing Reynolds number is lower than rate of increase of friction factor because reattachment of free shear layer does not occur and rate of heat transfer enhancement is not proportional to that of friction factor at higher values of relative roughness height. Bhushan and Singh [43] performed experiments on solar air heater duct with circular protrusions in order to determine the Nusselt and friction factor, which give qualitative idea of efficiency of the solar air heater. They validated their experimental data for Nusselt number and friction factor with Dittus-Boelter and modified Blasius correlations, respectively. On comparison with smooth duct, they observed a maximum enhancement of 3.8 times and 2.2 times in Nusselt number and friction factor, respectively. Yadav et al. [44] experimented with rectangular duct of solar air heater, which is roughened by circular protrusions oriented in angular arc. The benefit of protrusion is that it does not add extra weight to the solar heater. The maximum enhancement of Nusselt number and friction factor, which occurs for arc angle value of $60^{\circ}$, is found to be 2.89 and 2.93, respectively. The numerical correlations developed for Nusselt number and friction factor have been found to be within deviations of $3.81 \%$ and $4.91 \%$, respectively. Bhattacharyya et al. [45] performed heat transfer enhancement experiments in a circular duct solar air heater having a combination of integral transverse ribs and centre-cleared twisted tape as artificial roughness. The major breakthrough reported is that centre-cleared twisted tapes integrated with transverse ribs gives significantly better results than the individual enhancement technique used alone. Kumar et al. [46] conducted experiments on solar air heater having multi $\mathrm{V}$-shaped with gap ribs in the Reynolds number range of 2000-20,000 for angle of attack between $30^{\circ}$ and $75^{\circ}$. The value of Nusselt number

Table 3

Heat transfer enhancement in water heaters.

\begin{tabular}{|c|c|c|c|c|c|}
\hline \multirow[t]{2}{*}{ Author(s) (Year) } & \multicolumn{2}{|c|}{ Structural modification } & \multirow[t]{2}{*}{ Range of parameters } & \multirow[t]{2}{*}{ System } & \multirow[t]{2}{*}{ Test fluid } \\
\hline & Shape & Material & & & \\
\hline $\begin{array}{l}\text { Garcia et al. (2005) } \\
\text { [49] }\end{array}$ & Wire coil & Steel & $\begin{array}{l}\text { Re }: 80-90,000 \\
\quad e / d=0.07-0.10 \\
d=18 \mathrm{~mm} \\
p / d=1.17-2.68 \\
\quad p / e=14-33\end{array}$ & Heat exchanger & $\begin{array}{l}\text { Water, Water-propylene } \\
\text { glycol }\end{array}$ \\
\hline
\end{tabular}

Jaisankar et al. (2009) Helical twisted tapes [51]

$\begin{array}{ll}\text { Promvonge et al. (2012) } & \begin{array}{l}\text { Twin twisted tapes coupled with helical Aluminum } \\ \text { ribbed }\end{array}\end{array}$

Garcia et al. (2013) [50] Wire coil

Azmi et al. (2014) [52] Twisted tape

Nanan et al. (2014) [54] Perforated helical twisted-tapes

$$
\begin{aligned}
& L=1 \mathrm{~m} \\
& d_{i}=11 \mathrm{~mm} \\
& d_{o}=12.5 \mathrm{~mm} \\
& \operatorname{Re}: 3000-23,000 \\
& \quad H / D=3-6
\end{aligned}
$$

$$
\begin{aligned}
& \text { Re }: 6000-60,000 \\
& e / D_{H}=0.06 \\
& p / D_{H}=0.27 \\
& Y=2.17-9.39 \\
& \text { Co-swirl with helical }
\end{aligned}
$$

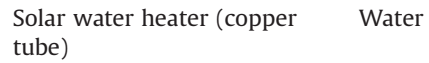

Water

$: 0.011-0.047 \mathrm{~kg} / \mathrm{s}$

Solar
tube

Heat exchanger (double copper Water tube)

$$
\begin{aligned}
& \text { Steel } \\
& \text { Aluminum } \quad \begin{array}{c}
L=011-0.047 \mathrm{~kg} / \mathrm{s} \\
\\
d_{i}=16 \mathrm{~mm} \\
d_{0}=19 \mathrm{~mm} \\
\operatorname{Re}: 8000-30,000 \\
\phi=0-3 \% \\
\\
\quad H / D=0-15
\end{array}
\end{aligned}
$$

$$
\begin{aligned}
& \text { Aluminum } \\
& \begin{array}{l}
\text { Re : } 6000-20,000 \\
d / w=0.2,0.4,0.6
\end{array} \\
& s / w=1,1.5,2 \\
& P / D=2 \\
& y / w=3 \\
& e / D=0.03
\end{aligned}
$$

Sandhu et al. (2014) [55] Twisted tape, wire coil and wire mesh Steel and

$$
\text { copper }
$$

$$
\begin{gathered}
\text { Re }: 200-8000 \\
L=0.915 \mathrm{~m} \\
d_{i}=13.4 \mathrm{~mm} \\
\quad d_{o}=16 \mathrm{~mm}
\end{gathered}
$$

Heat exchanger

Water

Solar water heater (copper Water tube)
Water

$\mathrm{TiO}_{2} /$ Water nanofluid 


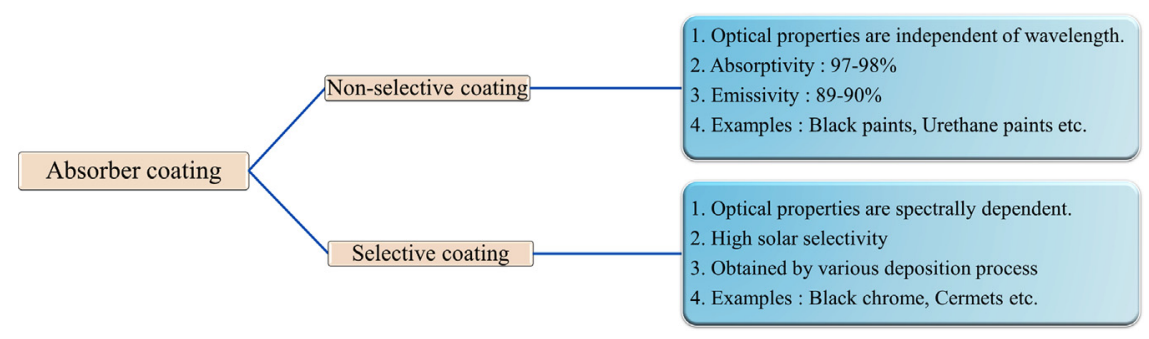

Fig. 14. Classification of solar coatings.

and friction factor was greater than that of duct with multi Vshaped without gap rib. This arrangement of artificial roughness exhibited an enhancement of Nusselt number up to 6.74 times for the angle of attack of $60^{\circ}$.

Kumar and Saini [47] used the computational fluid dynamics to analyze the performance of a solar air heater after incorporation of artificial roughness in the form of thin circular wire. With increase in Reynolds number, Nusselt number is seen to increase, whereas the friction factor decreases for all combinations of relative roughness height and relative arc angle. Karwa and Chauhan [48] theoretically worked on the evaluation of performance of a solar air heater having V-down discrete rectangular cross-section repeated rib roughness. After analyzing the results, it was suggested that at low mass flow rate the roughened duct solar air heaters give significantly better effective efficiency while due to considerably large increase in pumping power at high mass flow rate, it is not advisable to use roughened duct.

In water heaters, the heat transfer rate is increased by using turbulence promoters such as twisted tape inserts, perforated twisted tape inserts, wire coil inserts, wire mesh etc. in the flow passage. Table 3 shows some recent studies on heat transfer augmentation in water heaters. Garcia et al. [49] used steel wire coil inserts to evaluate the in-tube heat transfer coefficient using water and water-propylene glycol as working fluids. The tests were conducted for laminar-transition-turbulent regimes. They found that the heat transfer rate increased by $200 \%$ for constant pumping power. It was also observed that the maximum enhancement occurred in transition regime. On the basis of these findings, later Garcia et al. [50] implemented wire coil inserts in the flat plate solar water heater. The tests were conducted for different mass flow rates in the range $0.011-0.047 \mathrm{~kg} / \mathrm{s}$. It was found that the wire-coil inserts increased thermal efficiency of the collector. 14-31\% increase in average thermal efficiency was reported for the mentioned range of mass flow rate. However, for higher mass flow rates, the increase in heat transfer rate was not significant.

Jaisankar et al. [51] performed experiments on helical twisted tape inserts with different twist ratios inside the copper tubes of flat plate solar water heater to determine the heat transfer and pressure drop characteristics. They used twisted tapes made up of copper. The Reynolds number was varied from 3000 to 23,000. It was found that with the increase in twist ratio, the swirl generation decreased resulting in both heat transfer rate and pressure drop. The use of twisted tapes reduced the collector area requirement by $8-24 \%$ for a given efficiency. Recently a similar study was conducted Azmi et al. [52] using aluminum made twisted tapes with a different test fluid. The test fluid was $\mathrm{TiO}_{2} /$ water nanofluid for concentrations ranging from $0 \%$ to $3 \%$. It was found that the heat transfer coefficient increased by a maximum of $23.2 \%$ at $1 \%$ concentration of nanoparticles. The increase in twist ratio caused a decrease in heat transfer coefficient. The thermo-hydraulic performance analyses showed that maximum advantage of both nanofluid and twisted tape inserts occurred at twist ratio of 15 and concentration of $1 \%$. Promvonge et al. [53] used twin twisted tapes inside a helicalribbed tube of double tube heat exchanger. The direction of both (tube and tapes) structural modifications was designed to create a co-swirl of the fluid. They found an improved overall performance with the proposed design compared to individual modifications. The highest thermal efficiency was achieved for twist ratio of eight.

It has been seen that the use of various types of inserts increases the heat transfer as well as pressure drop. A modification in the twisted tape by perforating it is expected to reduce the pressure drop and increase the turbulence further. Nanan et al. [54] experimented with perforated helical aluminum twisted tapes. It was found that maximum performance was achieved for 0.2 diameter ratio $(d / w)$ and 2 pitch ratio $(s / w)$ at the Reynolds number of 6000 . Sandhu et al. [55] investigated three different inserts namely, twisted, wire coil, and wire mesh to evaluate the performance of solar water heater. The concentric wire coils were found to be the best among all other inserts. The heat transfer coefficient increased by 110\% at low Reynolds number and $460 \%$ at high Reynolds number.

\subsection{Solar selective coatings}

An efficient way to maximize the harnessing of solar insolation is to apply coatings of some specific materials on the absorber surface. Coatings are broadly classified as non-selective coatings, and solar selective coatings, as shown in Fig. 14. The optical properties like reflectivity, absorptivity, emissivity etc. of nonselective coatings are spectrally uniform, that implies optical characteristics of such coatings are independent of wavelength over a particular wavelength range. These coatings have poor solar selectivity and also they are thermally unstable at an elevated temperature resulting in poor absorber efficiency. One of the examples for non-selective coatings is ordinary black paint applied on the absorbers' surface. It increases both absorptivity and emissivity. In solar thermal application, a coating should have a high absorptivity but a low emissivity, so that it retains the trapped thermal energy. This limits the applicability of nonselective coatings for solar thermal conversion technology. That is why researchers gave less attention to these coatings. Nevertheless, recently Tulchinsky et al. [56] synthesized a new nonselective coating formed by thermal reaction of sol-gel titania with copper manganese spinel. This novel thermal coating $\mathrm{Cu}_{0.44} \mathrm{Ti}_{0.44} \mathrm{Mn}_{0.84} \mathrm{Fe}_{0.28} \mathrm{O}_{3}$ exhibits bixbyite structure and has an absorptivity of greater than $95 \%$ in the visible range. This coating can be applied with ease either manually or by spray technique. It has potential to be employed for solar thermal conversion. However, synthesis of some more new coatings with other similar combination of materials needs to be examined for further optimizing its optical properties.

Solar selective coatings, on the other hand, have different absorptivity and emissivity in different spectral regions. It means that the optical properties are spectrally dependent. From StefanBoltzmann law the energy emitted by a body is proportional to fourth power of its absolute temperature. Also, from Planck's law, the photonic energy of radiation is inversely proportional to it wavelength. This means a body at high temperature will emit thermal radiation at shorter wavelength and vice-versa. Thus, the 
incoming solar radiation has shorter wavelength and thermal radiation emitted by the absorber surface will obviously have longer wavelength. The solar selective coatings allow incoming solar radiation to pass through it and block the emittance of longer wavelength thermal radiation. Thus, they help in capturing the radiative energy to achieve high temperatures. There are many types of coatings based on different absorption mechanisms such as light trapping, particulate coatings, semiconductor-metallic layers, multi-layer films, quantum size effects, and intrinsic absorption. Besides having a long-term thermal stability, these coatings should have high absorptivity in the $0.3-2.5 \mu \mathrm{m}$ spectral range and low emissivity in the far infrared range $(0.7 \mu \mathrm{m}$ onwards) for given operating range of temperature [57]. The optical characteristic of a coating is defined in terms of 'solar selectivity', which is the ratio of solar absorptivity to emissivity at a given temperature. By improving the optical characteristic and making it thermally stable at high temperatures will eventually increase the working fluid temperature, thereby improving the overall efficiency of solar collectors. There are numerous processes, in principle, to achieve selective solar absorbing surfaces. The

Table 4

Selective experimental studies on solar selective coatings.

\begin{tabular}{|c|c|c|c|c|c|c|}
\hline \multirow[t]{2}{*}{ Author(s) (Year) } & \multicolumn{2}{|l|}{ Material } & \multirow[t]{2}{*}{$\alpha$} & \multirow[t]{2}{*}{$\varepsilon$} & \multirow[t]{2}{*}{ Technique used } & \multirow[t]{2}{*}{ Conclusions } \\
\hline & Substrate(s) & Coating(s) & & & & \\
\hline Abbas (2000) [58] & $\begin{array}{l}\text { Nickel plated } \\
\text { copper }\end{array}$ & Black chrome & 0.96 & 0.12 & $\begin{array}{l}\text { Electrochemical } \\
\text { treatment }\end{array}$ & $\begin{array}{l}\text { - Make solar collectors better efficient thermally by more than } 30 \% \\
\text { - Good thermal stability up to } 300{ }^{\circ} \mathrm{C}\end{array}$ \\
\hline $\begin{array}{l}\text { Schuler et al. (2000) } \\
\text { [59] }\end{array}$ & Aluminum & $\mathrm{a}-\mathrm{C}: \mathrm{H} / \mathrm{Ti}$ & 0.876 & 0.06 & PVD/PECVD & $\begin{array}{l}\text { - Selectivity as high as } 14.4 \text { is achieved without optimizing thickness } \\
\text { - Service life is predicted to be more than } 25 \text { years }\end{array}$ \\
\hline $\begin{array}{l}\text { Teixeira et al. } \\
\text { (2001) [61] }\end{array}$ & $\begin{array}{l}\text { Glass, Aluminum } \\
\text { and Copper }\end{array}$ & $\begin{array}{l}\mathrm{Cr}-\mathrm{Cr}_{2} \mathrm{O}_{3} / \\
\mathrm{Mo}-\mathrm{Al}_{2} \mathrm{O}_{3}\end{array}$ & $\begin{array}{l}0.88- \\
0.94\end{array}$ & $\begin{array}{l}0.15- \\
0.04\end{array}$ & $\begin{array}{l}\text { Magnetron } \\
\text { sputtering }\end{array}$ & $\begin{array}{l}\text { - Composite coatings offer excellent thermal stability } \\
\text { - Need to optimize the optical behavior of coatings by simulation }\end{array}$ \\
\hline $\begin{array}{l}\text { Farooq and } \\
\text { Hutchins (2002) } \\
{[62,63]}\end{array}$ & $\begin{array}{l}\text { Copper and } \\
\text { aluminum }\end{array}$ & $\mathrm{V}-\mathrm{Al}_{2} \mathrm{O}_{3}$ & 0.98 & 0.02 & $\begin{array}{l}\text { Magnetron } \\
\text { sputtering }\end{array}$ & $\begin{array}{l}\text { - Number of layers were insignificant beyond a critical number } \\
\text { - Four layer PGSAC gives the best efficiency }\end{array}$ \\
\hline $\begin{array}{l}\text { Cindrella (2007) } \\
\text { [64] }\end{array}$ & $\begin{array}{l}\text { Nickel-plated } \\
\text { copper }\end{array}$ & $\mathrm{Co}-\mathrm{Cd} / \mathrm{Ni}-\mathrm{Cd}$ & 0.93 & 0.07 & $\begin{array}{l}\text { Electro- } \\
\text { deposition }\end{array}$ & $\begin{array}{l}\text { - Selective coating is required essentially only for flat plate collectors } \\
\text { - Low emittance coating required for unity concentration ratio systems }\end{array}$ \\
\hline $\begin{array}{l}\text { Shashikala et al. } \\
\text { (2007) [65] }\end{array}$ & $\begin{array}{l}\text { Nickel-plated } \\
\text { aluminum alloy }\end{array}$ & Black Ni-Co & 0.948 & 0.17 & $\begin{array}{l}\text { Electrochemical } \\
\text { treatment }\end{array}$ & $\begin{array}{l}\text { - Nickel undercoat influences the optical properties substantially } \\
\text { - Suitable for space applications too }\end{array}$ \\
\hline $\begin{array}{l}\text { Wazwaz et al. } \\
\text { (2010) [66] }\end{array}$ & Aluminum alloy & $\mathrm{Ni}$ & 0.892 & 0.052 & $\begin{array}{l}\text { Electrochemical } \\
\text { treatment }\end{array}$ & $\begin{array}{l}\text { - Average thermal efficiency increases with increase in Nickel content } \\
\text { - Exists an optimum limit of nickel that gives the optimum efficiency }\end{array}$ \\
\hline $\begin{array}{l}\text { Juang et al. (2010) } \\
\text { [67] }\end{array}$ & Glass & SS/SS-N & 0.91 & 0.06 & $\begin{array}{l}\text { Magnetron } \\
\text { sputtering }\end{array}$ & $\begin{array}{l}\text { - Fabricated high solar selectivity composite coating by the use of only one } \\
\text { sputtering target having flexibility to control thickness of layers }\end{array}$ \\
\hline Du et al. (2011) [68] & Silicon & $\begin{array}{l}\mathrm{Ti}_{0.5} \mathrm{Al}_{0.5} \mathrm{~N} / \\
\mathrm{Ti}_{0.25} \mathrm{Al}_{0.75}\end{array}$ & 0.945 & 0.04 & $\begin{array}{l}\text { Magnetron } \\
\text { sputtering }\end{array}$ & $\begin{array}{l}\text { - Metallic character is exhibited by } \mathrm{Ti}_{0.5} \mathrm{Al}_{0.5} \mathrm{~N} \text { and resembles } \mathrm{Na}-\mathrm{Cl} \\
\text { - Semiconducting character is exhibited by } \mathrm{Ti}_{0.25} \mathrm{Al}_{0.75}\end{array}$ \\
\hline Liu et al. (2012) [70] & $\begin{array}{l}\text { Copper and } \\
\text { stainless steel }\end{array}$ & $\begin{array}{l}\text { NbTiON/ } \\
\text { SiON }\end{array}$ & 0.95 & 0.07 & $\begin{array}{l}\text { Magnetron } \\
\text { sputtering }\end{array}$ & $\begin{array}{l}\text { - Oxidation and diffusion of copper degrades film at high temperature } \\
\text { - Coating on SS exhibits better thermal stability above } 500{ }^{\circ} \mathrm{C}\end{array}$ \\
\hline $\begin{array}{l}\text { Nuru et al. (2012) } \\
\text { [71] }\end{array}$ & $\begin{array}{l}\text { Glass, silicon and } \\
\text { copper }\end{array}$ & $\begin{array}{l}\mathrm{Al}_{x} \mathrm{O}_{y} / \mathrm{Pt} / \\
\mathrm{Al}_{x} \mathrm{O}_{y}\end{array}$ & 0.94 & 0.01 & Electron beam & $\begin{array}{l}\text { - Dielectric/metal/dielectric coating exhibits high performance } \\
\text { - Increase in surface roughness of coating layers with temperature }\end{array}$ \\
\hline $\begin{array}{l}\text { Khamlich et al. } \\
\text { (2013) [73] }\end{array}$ & Tantalum & $\mathrm{Cr} / \alpha-\mathrm{Cr}_{2} \mathrm{O}_{3}$ & 0.90 & 0.28 & $\begin{array}{l}\text { Aqueous } \\
\text { chemical } \\
\text { growth }\end{array}$ & $\begin{array}{l}\text { - Optical properties are the function of annealing temperature } \\
\text { - More suitable for absorbers required for temperature below } 600{ }^{\circ} \mathrm{C}\end{array}$ \\
\hline Liu et al. (2014) [74] & Stainless steel & $\mathrm{Cr}-\mathrm{Al}-\mathrm{O}$ & 0.924 & 0.21 & $\begin{array}{l}\text { Cathodic arc ion } \\
\text { plating }\end{array}$ & $\begin{array}{l}\text { - } \mathrm{Cr}_{2} \mathrm{Al} \text { nanograins intrinsic absorption property cause high absorptivity } \\
\text { - Excellent thermal stability, suitable for collectors at high temperature }\end{array}$ \\
\hline $\begin{array}{l}\text { Valleti et al. (2014) } \\
\text { [75] }\end{array}$ & $\begin{array}{l}\text { Copper and } \\
\text { stainless steel }\end{array}$ & $\begin{array}{l}\text { TiAlCrN/ } \\
\text { TiAlN/AISiN }\end{array}$ & 0.91 & 0.07 & $\begin{array}{l}\text { Cathodic arc } \\
\text { PVD }\end{array}$ & $\begin{array}{l}\text { - Excellent thermal stability of coating at elevated temperature } \\
\text { - Substrate degrades at high temperature, need better alternate substrate }\end{array}$ \\
\hline $\begin{array}{l}\text { Cespedes et al. } \\
\quad(2014)[76]\end{array}$ & $\begin{array}{l}\text { Silicon and } \\
\text { stainless steel }\end{array}$ & $\mathrm{Mo}-\mathrm{Si}_{3} \mathrm{~N}_{4}$ & 0.926 & 0.017 & $\begin{array}{l}\text { Magnetron } \\
\text { sputtering }\end{array}$ & $\begin{array}{l}\text { - Highest selectivity ratio at temperature above } 600{ }^{\circ} \mathrm{C} \\
\text { - Potential to be used as coating for CSP technology }\end{array}$ \\
\hline $\begin{array}{l}\text { Kumar et al. (2014) } \\
\text { [77] }\end{array}$ & Copper & $\begin{array}{l}\mathrm{CuO} \\
\text { nanoparticles }\end{array}$ & 0.84 & 0.06 & $\begin{array}{l}\text { Chemical } \\
\text { treatment }\end{array}$ & $\begin{array}{l}\text { - Coating nanostructures varies with } \mathrm{pH} \text { of reaction } \\
\text { - Multiple absorption takes place in porus structure of coating }\end{array}$ \\
\hline
\end{tabular}


challenge lies in developing coatings, which should not only be compatible with absorber surface but also economical and easy to produce in bulk.

Table 4 shows the research on different types of solar selective coatings. Abbas [58] argued that black chrome or solchrome, which is a metal-based coating, has high absorptivity and requires very less maintenance. He conducted experimental evaluation on three collector types viz. solchrome tig welded fin and tube collector, solchrome omega soldered fin and tube collector, and black painted omega soldered fin and tube collector. Solchrome coatings were found to enhance the collector efficiency by more than $30 \%$ even for low temperature applications. Schuler et al. [59,60] developed titanium containing amorphous hydrogenated carbon coating (a-C:H/Ti) and amorphous hydrogenated silicon carbon coating (a-Si:C:H/Ti) by combined PVD and PECVD process. Amorphous hydrogenated carbon coating was prepared by sequential deposition of three layers viz. pure $\mathrm{Ti}, \mathrm{a}-\mathrm{C}: \mathrm{H} / \mathrm{Ti}$ and pure $\mathrm{a}-\mathrm{C}: \mathrm{H}$ on the substrate. The optical properties were reported to be a function of various parameters and strongly dependent upon the quantity of titanium. Without performing any optimization, the developed a-C: $\mathrm{H} / \mathrm{Ti}$ coating yielded a solar selectivity of 14.4 at a temperature of $100{ }^{\circ} \mathrm{C}$. On conducting accelerated aging test with aluminum as substrate, the service life period of coating was predicted to be 25 years. Later they fused silicon in the preparation of coating and claimed to significantly enhance the lifetime stability, irrespective of the substrates, than former. Silicon posed challenge of fast degradation under humid conditions but it can be well controlled by controlling the content of silicon. Nonetheless, this coating is a very

Table 5

Comparison of thermal conductivity of additives and base fluids.

\begin{tabular}{lll}
\hline Material & & Thermal conductivity (W/m K) \\
\hline \multirow{2}{*}{ Metallic solids } & Iron & 83.5 \\
& Aluminum & 237 \\
& Gold & 318 \\
& Copper & 401 \\
& Silver & 428 \\
Non-metallic solids & $\mathrm{Al}_{2} \mathrm{O}_{3}$ & 40 \\
& $\mathrm{CuO}$ & 76.5 \\
& $\mathrm{Si}$ & 148 \\
& $\mathrm{SiC}$ & 270 \\
& $\mathrm{BNNT} \quad$ (MWCNT) & $3000-600$ \\
& CNT (SWCNT) & 6000 \\
& & 0.613 \\
Base fluids & Water & 0.253 \\
& Ethylene glycol & 0.145 \\
\hline
\end{tabular}

good candidate for vacuum collectors since they have long service time under high temperature. Teixeira et al. [61] produced a spectrally dependent multilayered coating having a thickness of about $300 \mathrm{~nm}$ based on metallic chromium and molybdenum embedded in the matrix of chromium oxide and aluminum oxide, respectively. The films were manufactured by reactive DC magnetron sputtering by keeping the oxygen supply in pulsated manner (oxygen flow was switched on and off) in order to produce multilayered structure. Copper and glass were used as substrates. They established reactive sputtering as a potential process for the production of graded selective coating with the benefit of controlling the addition of metallic phases. However, they emphasized the use of numerical simulation beforehand in order to optimize the coating properties before its actual production. Farooq and Hutchins $[62,63]$ developed a multilayer metal-dielectric graded index spectrally dependent coating using co-sputtering technique. They performed computer simulation beforehand to understand the role of various parameters like number of layers, thickness of each layers, best combination of metal-dielectric matrix etc. and to optimize them. Experiments too were conducted to validate the computer model findings. Beyond a certain number of layers, the variation in optical performance was found not to be considerable. Out of the investigated batch of coatings, four layer prime graded selective absorber coating of $\mathrm{V}: \mathrm{Al}_{2} \mathrm{O}_{3}$ gave the best result with solar absorptivity of 0.98 and emissivity of 0.02 . Cindrella [64] critically analyzed the effectiveness of selective coatings in solar thermal systems of different concentration ratios with respect to two composite solar selective coatings: cobalt-cadmium and nickel-cadmium. It was found that a coating with high value of absorptivity is essential for solar thermal systems with higher concentration ratio $(C R>10)$ where as low emittance coatings should be taken for systems with unity concentration ratio. Shashikala et al. [65] investigated nickelcobalt coating keeping aluminum alloy with nickel undercoat as substrate. Even though nickel undercoat was applied to resist the corrosion, its thickness was found to influence optical properties of the coating. The nickel undercoat thickness was optimized at 5-7.5 $\mu \mathrm{m}$. Hull cell experiments were used to optimize the electrochemical process of coating preparation. The resultant selective coating was put under various tests such as humidity, thermal cycling, thermal stability etc. and it exhibited good environmental stability making it suitable not only at earth's surface but also in space. It has solar absorptivity and emissivity of 0.948 and 0.17 , respectively. In a similar study, Wazwaz et al. [66] inspected the effects of nickel content and alumina layer thickness in a selective coating on aluminum alloy substrates. Solar selectivity was found to be proportional to amount of nickel. However, there existed a limit of $60 \mu \mathrm{g} / \mathrm{cm}^{2}$ of nickel content for the maximum selectivity and thermal efficiency. Juang et al. [67] fabricated a stainless

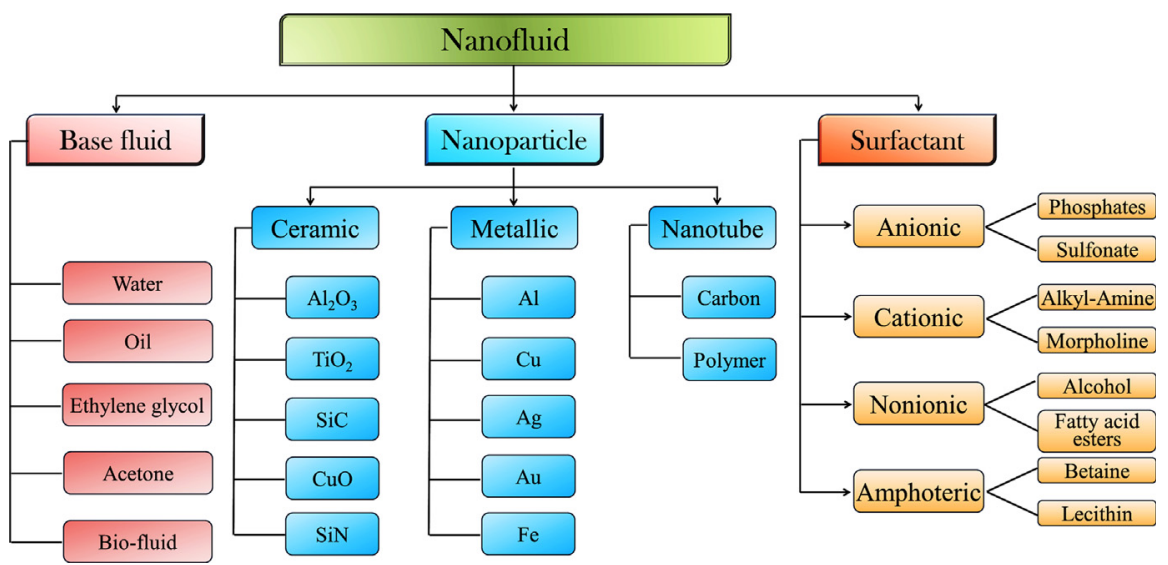

Fig. 15. Constituents of nanofluid and their common examples. 
steel/stainless steel nitride (SS/SS-N) cermet thin coating using reactive sputtering. Based on flow variation of nitrogen gas, high metal volume fraction and low metal volume fraction coatings were produced. The produced composite selective coating has solar absorptance of 0.91 and low thermal emittance of 0.06 at $82{ }^{\circ} \mathrm{C}$. $\mathrm{Du}$ et al. [68,69] developed and optimized a novel multilayer selective coating consisting $\mathrm{Ti}_{0.5} \mathrm{Al}_{0.5} \mathrm{~N}$ and $\mathrm{Ti}_{0.25} \mathrm{Al}_{0.75} \mathrm{~N}$ as absorber layers and AlN as anti-reflection layer. The optimization was achieved using computer program TFCalc. The produced fourlayered (AlN being dielectric) solar selective coating has a solar absorptance of 0.91 and a low thermal emittance of 0.06 at $82{ }^{\circ} \mathrm{C}$. The coating was found to be stable till approximately $500{ }^{\circ} \mathrm{C}$ in air. However, diffusion of oxygen causes degradation beyond $500{ }^{\circ} \mathrm{C}$. Liu et al. [70] developed solar selective film having NbTiON and SiON layers on copper and stainless steel substrates using magnetron sputtering. The optimized thickness was found experimentally as $150 \mathrm{~nm}$ and $70 \mathrm{~nm}$ for NbTiON and SiON layers, respectively. The coating exhibited better thermal stability on stainless steel substrate at an elevated temperature. Nuru et al. [71,72] prepared solar selective multilayer coating $\mathrm{Al}_{x} \mathrm{O}_{y} / \mathrm{Pt} / \mathrm{Al}_{x} \mathrm{O}_{y}$ on glass, silicon and copper substrates using electron beam evaporator technique. This coating was based on dielectric/metal/dielectric arrangement. Both $\mathrm{Al}_{x} \mathrm{O}_{y}$ layers were dielectric in nature, whereas Pt layer was semitransparent. Ellipsometric measurements and optical simulation were used to optimize the parameters. An optimized coating having thickness of $1370 \AA$ deposited on copper demonstrated a solar selectivity of 15.6. While performing thermal stability test, there was a sharp decline in the intensity of Pt grain in the temperature range of $300-600{ }^{\circ} \mathrm{C}$ and it completely vanished forming $\mathrm{CuO}$ and $\mathrm{Cu}_{2} \mathrm{O}$ at $700{ }^{\circ} \mathrm{C}$. Khamlich et al. [73] produced chromium/alphachromium (III) oxide absorber coating on tantalum substrate using a novel and cost-effective approach named as aqueous chemical growth method. This method is simple, cheap, and provides better control of parameters. Annealing done in the temperature range of $400-500{ }^{\circ} \mathrm{C}$ exhibited selectivity comparable to black chrome coating. X-ray diffraction and attenuated total reflection results established that such coatings are excellent for the application in systems with temperature range below $600{ }^{\circ} \mathrm{C}$. Liu et al. [74] developed a four layer coating based on chromium-aluminum-oxygen by the process of cathodic arc ion plating. Different layers were obtained by varying the oxygen concentration. On conducting tests on spectrophotometer and Raman spectroscopy to determine its optical properties and thermal stability respectively, it was found that it has solar absorptance of 0.924 and emittance of 0.021 . This coating can be employed for solar thermal systems operating at temperature above $600{ }^{\circ} \mathrm{C}$. Valleti et al. [75] fabricated a multilayered nitride based coating on copper and stainless steel using cathodic arc physical vapor deposition. The coating has three layers namely, TiAlCrN as infrared reflector, TiAlN as absorber, and AISiN as antireflective layer. On the one hand, the absorber layer TiAlN deposited at moderate nitrogen partial pressure with minimal $\mathrm{Ti}$ content exhibits high absorptance properties, on the other hand infrared reflector layer TiAlCrN deposited at high chromium content results in better absorptance properties. This multilayered selective coating presented a good thermal stability at high temperature with solar selectivity of 13 . However, the substrates' steel degradation was observed at elevated temperatures, leaving a scope of investigation for a better alternative substrate. Cespedes et al. [76] deposited multilayered selective coating using magnetron sputtering after optimizing it through optical simulations. It consists of silver infrared reflector, molybdenum-silicon nitride as absorber and silicon nitride as anti-reflective layer. This $\mathrm{Mo}-\mathrm{Si}_{3} \mathrm{~N}_{4}$ cermet-based spectrally dependent coating demonstrated a high solar absorptivity of 0.926 and a low thermal emissivity of 0.017 even at temperature as high as $600^{\circ} \mathrm{C}$; making it suitable for solar concentrated power technology. Kumar et al. [77] recently prepared spectrally dependent coating at room temperature by chemical oxidation of copper at various alkaline conditions. The nanostructure of copper oxide layer was found to be dependent on $\mathrm{pH}$ of the preparing solution. The porous nature of nanostructures causes multiple absorptions. The coating possessed solar selectivity of 12 , making it suitable for photo-thermal conversion.

\subsection{Nanofluids}

Thermal properties of liquids play a decisive role in heating as well as cooling applications in industrial processes. Thermal conductivity of a liquid is an important physical property that decides its heat transfer performance. Conventional heat transfer fluids like water, oil, ethylene glycol etc. have inherently poor thermal conductivity, which makes them unfit for applications where high heat transfer rate is required. There are continuous attempts to enhance the inherently poor thermal conductivity of these conventional heat transfer fluids using highly conducting solid additives. However, if the particulate size of solid additive is kept in order of micrometer or larger, it has the drawbacks of particle sedimentation, corrosion of components of systems, particle clogging, excessive pressure drop etc. These problems get reduced significantly if the particle size of solid phase is of order of nanometer, and the resulting fluid is known as nanofluid. Nanofluids are dilute liquid suspensions of nanoparticles with at least one of their principal dimensions smaller than $100 \mathrm{~nm}$ [78]. The striking features which made nanoparticles suitable candidates for suspension in fluids are small size and a large surface area, less particle momentum, and high mobility. Due to very small sizes and large specific surface areas of the nanoparticles, nanofluids have many superior properties like minimal clogging in flow passages, long-term stability, homogeneity, other than having an obvious high thermal conductivity; thermal conductivity of common solid additives and base fluids is given in Table $5[79,80]$. To achieve a stable nanofluid, the particles should be dispersed in base fluids with no or very little agglomeration. This can be done through various methods, including electrical, physical, or chemical. In the literature,

Table 6

Classification of nanofluids based on nanoparticles' volume fraction.

\begin{tabular}{lll}
\hline Types of nanofluid & Shape of nanoparticles & Volume fraction of nanoparticles $(\varphi)$ \\
\hline \multirow{2}{*}{ Dilute nanofluid } & Spherical & $0<\varphi<\sim 0.001$ \\
& Tubular or rod-like $(r=$ length/diameter $)$ & $0<\varphi<1 / r^{2}$ \\
Semi-dilute nanofluid & Spherical & $\sim 0.001<\varphi<\sim 0.05$ \\
& Tubular or rod-like & $1 / r^{2}<\varphi<1 / r$ \\
Semi-concentrated nanofluid & Spherical & $\sim 0.05<\varphi<\sim 0.10$ \\
& Tubular or rod-like & $1 / r<\varphi<\varphi^{r}$ \\
Concentrated nanofluid & Spherical & $\varphi>\sim 0.10$ \\
& Tubular or rod-like & $\varphi>1 / r$ \\
\hline
\end{tabular}


Table 7

Reviews on heat transfer augmentation using nanofluids.

\begin{tabular}{|c|c|c|}
\hline Author(s) Years & $\begin{array}{l}\text { Aspect of nanofluids } \\
\text { presented }\end{array}$ & Remarks \\
\hline $\begin{array}{l}\text { Wang and Majumdar (2007) } \\
\text { [80] }\end{array}$ & $\begin{array}{l}\text { Heat transfer } \\
\text { characteristics }\end{array}$ & - Investigation focused on thermal conductivity rather than heat transfer characteristics \\
\hline $\begin{array}{l}\text { Trisaksri and Wongwises } \\
\text { (2007) [90] }\end{array}$ & $\begin{array}{l}\text { Heat transfer } \\
\text { characteristics }\end{array}$ & - No agreement over best model to use for the thermal conductivity of nanofluids \\
\hline Saidur et al. (2011) [95] & $\begin{array}{l}\text { Applications and } \\
\text { challenges }\end{array}$ & - Exact mechanism of enhanced heat transfer for nanofluids is still unclear \\
\hline \multirow[t]{2}{*}{ Haddad et al. (2012) [91] } & $\begin{array}{l}\text { Natural convective heat } \\
\text { transfer }\end{array}$ & - Two phase flow model has more accuracy \\
\hline & & - Presence of nanoparticles deteriorates heat transfer systematically \\
\hline Ahmed et al. (2012) [92] & $\begin{array}{l}\text { Heat transfer } \\
\text { augmentation }\end{array}$ & $\begin{array}{l}\text { - Varying experimental results about the pressure drop associated to the suspension of nanoparticles in the } \\
\text { base fluid }\end{array}$ \\
\hline $\begin{array}{l}\text { Chandrasekar et al. (2012) } \\
\text { [93] }\end{array}$ & $\begin{array}{l}\text { Forced convective heat } \\
\text { transfer }\end{array}$ & - Best combination of nanoparticle and base fluid to be selected to optimize thermophysical properties \\
\hline $\begin{array}{l}\text { Sureshkumar et al. (2013) } \\
\text { [94] }\end{array}$ & $\begin{array}{l}\text { Heat transfer } \\
\text { characteristics }\end{array}$ & - Hybrid nanofluids are not more effective compared with the pure nanoparticles nanofluid system \\
\hline Mahian et al. (2013) [96] & $\begin{array}{l}\text { Applications in solar } \\
\text { energy }\end{array}$ & $\begin{array}{l}\text { - Need to find the optimum volume fraction } \\
\text { - Vagaries in effect of particle size on the efficiency of collectors }\end{array}$ \\
\hline $\begin{array}{l}\text { Nkurikiyimfura et al. (2013) } \\
\text { [97] }\end{array}$ & Magnetic nanofluid & $\begin{array}{l}\text { - Solar radiation could be completely absorbed in a magnetic nanofluid layer with about } 10-\mathrm{mm} \text { thickness } \\
\text { - Studies regarding the parameter effects on the overall heat transfer coefficient and the fluid flow within } \\
\text { the system still are needed }\end{array}$ \\
\hline Kamyar et al. (2012) [98] & Computational techniques & $\begin{array}{l}\text { - Flow of nanofluid in different geometries can be modeled using Lattice Boltzmann Method } \\
\text { - Two-phase model for a nanofluid is more accurate }\end{array}$ \\
\hline
\end{tabular}

the commonly used dispersion technique is ultrasonic or stator-rotor method [81-85]. Sometimes stabilizing agents are also used during dispersion and they are called surfactant or dispersants $[85,86]$. The base fluids usually used for nanofluids are water, ethylene glycol, transformer oil, and toluene. The nanoparticles that are used may be broadly categorized into three groups: ceramic particles, pure metallic particles, and carbon nanotubes (CNTs). Different combinations of these base fluids and nanoparticles fluids give different nanofluids. Thus, based on nanoparticles dispersed in base fluids, there are three major types of nanofluids, namely ceramic nanofluids, metallic nanofluids, and carbon nanotube nanofluids, as shown in Fig. 15 $[79,87,88]$. Moreover, the concentration of nanoparticles also decides the properties of nanofluids; it means that the similar combination of base fluid and nanoparticles in different concentrations will have different properties. Based on the concentration of nanoparticles in the base fluid, nanofluids are categorized as dilute, semi-dilute, semiconcentrated, and concentrated nanofluids, more details are provided in Table 6 [89].

Despite considerable research efforts and significant progress in the past decade, the fundamental understanding of nanofluids is limited. This is indeed echoed through the significant scattering or disagreement of results reported in the literature. A few important studies related to various aspects of nanofluids have been presented in Table 7. Wang and Majumdar [80] summarized the heat transfer characteristics of nanofluids and reported that the field is still in infancy and its development faces challenges like the lack of agreement between experimental results from different groups, the often below par performance of suspensions, and lack of theoretical understanding of the mechanisms of their heat enhancing characteristics. Trisaksri and Wongwises [90] critically reviewed the heat transfer characteristics of nanofluids and concluded that the quality of nanofluids of enhancing thermal conductivity is dependent upon type of base fluid and nanoparticles, size and shape of nanoparticles, the particle volume fraction, $\mathrm{pH}$ value of nanofluids and type of particle coating. The natural convective heat transfer of nanofluids is different from that of the common suspensions in that the particles concentration gradient is absent. The issue in exactly claiming about nanofluids is that it is still not clear which is the best model to use for the thermal conductivity of nanofluids. It is predicted from the analytical investigation that with increase in particle volume fraction and density of nanoparticles, the natural convective heat transfer of nanofluids should increase. The experimental findings are in disagreement to the analytical results. Haddad et al. [91] studied the literature on natural convective heat transfer of nanofluids for both single and two-phase models which is significant for understandings of solar water heating systems. Most of the numerical results have claimed of heat transfer enhancement by using nanofluids but on experimental investigation it was found that nanoparticles degrade heat transfer systematically. Since the experimental results are mostly obtained using one type of nanofluid $\left(\mathrm{Al}_{2} \mathrm{O}_{3}\right.$-water), there is dire need of benchmark experiments for the validation of the numerical results. Numerical studies trying to explain the observed anomalous enhancement in heat transfer should be based on twophase approach as it considers slip velocity between the particle and base fluid, which plays an important role on the heat transfer performance of nanofluids. Ahmed et al. [92] extensively studied the heat transfer augmentation technique using nanofluids and observed that presence of nanoparticles is more effective at the smaller inclination angles. The variation in thermo-physical properties of nanofluids is caused by the amount of the agglomeration of nanoparticles as well as the formation of compressed phase. The effective viscosities and effective thermal conductivities of nanofluid are related to the aggregates of nanoparticles. They also found that the increase in pumping power as a result of large pressure drop and 
long-term fluid settling combined with potential clogging of flow passages are demerits of nanofluids. Chandrasekar et al. [93] comprehensively studied the experimentally proposed mechanisms on thermophysical and forced convective heat transfer characteristics of different nanofluids. They observed that increased thermal conductivity of nanofluid could be better understood by affirmations such as exhibition of Brownian motion by nanoparticles at higher temperatures or microstructural examination could provide better insight. Viscosity of nanofluid decreases with increase in temperature, whereas it increase with decrease in particle size. Increase in particle concentration increases viscosity but relation is not definite, it may be linear or nonlinear. Classical mixing theory is sufficient to predict the density of nanofluids. Sureshkumar et al. [94] studied both the theoretical and experimental investigation for the heat transfer characteristics of nanofluids. It is concluded that the reason for attaining higher heat transfer is due to higher wettability of nanofluids and increase in effective liquid conductance. On one hand the volume fraction of nanoparticles increases the thermal efficiency and on the other hand it reduces the thermal resistance significantly in comparison to base fluid. Saidur et al. [95] did a study on applications and challenges of nanofluids and mentioned that the presence of nanoparticles increases the absorption of incident radiation by more than nine times over that of pure water. Nanofluids stability and its production cost are major factors that hinder the commercialization of nanofluids. Mahian et al. [96] exclusively reviewed the applications of nanofluids in solar energy. It is found that some factors such as adding surfactant to nanofluid and a suitable selection of the $\mathrm{pH}$ of nanofluid are effective in the collector efficiency. It is also imperative that nanofluids in different volume fractions should be tested to find the optimum volume fraction as higher volume fraction always is not the best option. Nkurikiyimfura et al. [97] reviewed the advancement in heat transfer enhancement by magnetic nanofluids and suggested that solar thermosyphons where the fluid flow and heat transfer process may be completely controlled by an external magnetic field could be the future design. Kamyar et al. [98] summarized the computational simulations performed to understand the behavior of nanofluids. Even though two-phase model gave good prediction, the need for better understanding the effect of Brownian motion on thermal behavior of nanofluids was emphasized. A shift from convection heat transfer model to radiation heat transfer model or boiling heat transfer model for nanofluids is a possibility.

Regardless of numerous investigations dedicated to the use of nanofluids for heat transfer enhancement in the last decade, there are no commercial nanofluid solar collectors yet. However, Taylor et al. [99] developed a laboratory-scale nanofluid dish collector and evaluated its performance. On the basis of testing and evaluation of this collector, they claimed that nanofluids have excellent potential for power tower solar thermal power plants. Efficiency improvement of the order of $5-10 \%$ is possible with a nanofluid receiver. Ideally, these enhancements could be realized with very little change in terms of materials, system design, and initial capital investment to the entire solar thermal system. If solar thermal power plants move to larger scale at sites having ideal solar insolation, nanofluid receivers show even more potential. They even performed statistical analysis for capital gain and estimated that that a $100 \mathrm{MW}$ nanofluid thermal plant operating in Tucson city of Arizona could add 3.5 million US dollar to the annual revenue. Some other studies on systems like heat pipe whose findings can be implemented in solar thermal conversion have been also performed. Naphon et al. [100] conducted the experiment on the copper heat pipe with titanium nanofluid of diameter $21 \mathrm{~nm}$ prepared using ultrasonic technique. With $0.10 \%$ volumetric concentration of titanium nanoparticles, the efficiency was found to be $10.60 \%$ higher. Similar study in more extensive manner was conducted by Hung et al. [101] with alumina nanofluids of 10-30 nm particle size. Heat pipe length from $0.3 \mathrm{~m}$ to $0.6 \mathrm{~m}$, tilt angle from $10^{\circ}$ to $90^{\circ}$, volume concentration ratio in the range of $20-80 \%$ and heating power
20-40 W were varied to examine their effect and find the optimal thermal performance parameters. For the heating rate of $40 \mathrm{~W}$, the maximum efficiency was recorded for $0.45 \mathrm{~m}$ long heat pipe as 56.3\%; however, the efficiency was better with nanofluid for all cases. It was also found that increasing the concentration of nanoparticles beyond a certain level does not enhance thermal efficiency because of high water adsorption. Noie et al. [102] studied the heat augmentation properties of $\mathrm{Al}_{2} \mathrm{O}_{3}-\mathrm{H}_{2} \mathrm{O}$ nanofluid for a two-phase closed thermosyphon (TPCT). $\mathrm{Al}_{2} \mathrm{O}_{3}$ with average particles' diameter $20 \mathrm{~nm}$ were dispersed in distilled water using ultrasonic technique in volume fraction range of $1 \%, 1.5 \%, 2 \%, 2.5 \%$ and $3 \%$. The efficiency of TPCT was better for all the concentrations of nanofluid than that of pure water. This study established the heat enhancement properties of the $\mathrm{Al}_{2} \mathrm{O}_{3}$ nanofluid. Saidur et al. [103] evaluated the effect of nanofluid properties on direct absorption solar collectors. They noticed that even though particle size has no or minimal effect on optical properties, the size should be below $20 \mathrm{~nm}$ so that Rayleigh scattering happens. Once the desired optical properties are obtained, the volume fraction should be kept minimal in order to eliminate clogging and instability in nanoparticles suspension. Yousefi et al. [104-106] reported an extensive experimental investigation on the effect of two different nanofluids, namely $\mathrm{Al}_{2} \mathrm{O}_{3}-\mathrm{H}_{2} \mathrm{O}$ and MWCNT- $\mathrm{H}_{2} \mathrm{O}$ (multi-wall carbon nanotube), on the efficiency of flat plate solar collectors in literature. Collectors with absorption area $1.51 \mathrm{~m}^{2}$ and above $95 \%$ pure respective nanoparticles with Triton X-100 as surfactant were taken for both the cases. For $\mathrm{Al}_{2} \mathrm{O}_{3}$ nanofluid of $15 \mathrm{~nm}$ diameter, it was found that the $0.2 \mathrm{wt} \% \mathrm{Al}_{2} \mathrm{O}_{3}$ nanofluid increases efficiency by $28.3 \%$ for the flow rate of $3 \mathrm{l} / \mathrm{min}$ as well as use of surfactant enhances efficiency by $15.63 \%$ maximum in comparison to $\mathrm{Al}_{2} \mathrm{O}_{3}$ nanofluid without surfactant However, 0.2 wt\% MWCNT nanofluid of $10-30 \mathrm{~nm}$ diameter decreases the efficiency without surfactant while increases with surfactant. It was observed that $0.4 \mathrm{wt} \%$ MWCNT increases efficiency without surfactant. On varying the $\mathrm{pH}$ of $0.2 \mathrm{wt} \%$ MWCNT nanofluid, it was seen that higher the difference between $\mathrm{pH}$ of nanofluid and $\mathrm{pH}$ of isoelectric point, higher is the efficiency of the collector. The findings are significantly different for these two different nanofluids giving a scope for the trials to search for the best nanofluids and optimize the parameters such as $\mathrm{pH}$ value, particle concentration, discharge rate etc. Recently, Sokhansefat et al. [107] developed a numerical model in finite volume based commercial software for predicting the heat transfer characteristics of $\mathrm{Al}_{2} \mathrm{O}_{3}$ /synthetic oil nanofluid in a parabolic trough collector. It was established that there was a direct dependency of heat transfer coefficient on the volumetric concentration of nanoparticles. The model was validated with the experimental results with deviation of less than $3.8 \%$.

Although nanofluids have opened the gate for extremely exciting potential applications, there are few key issues associated with it and they must receive greater attention in the future investigations. There is a need of in-depth experimental and theoretical researches to facilitate the exact and systematic understanding of factors influencing the performance of nanofluids. Up to now, there is a lack of agreement between experimental results from different groups as well as experimental and analytical investigations are in disagreement. The detailed and precise characterizations of structure of the suspensions may be the key to explain the discrepancy in the experimental data. Increase in viscosity by the use of nanofluids, which cause increase in pumping power, is also a concern. Long-term stability of the suspension in base fluids in the practical conditions where there is possibility of varying and high temperatures should be given more attention. Finally, the properties of nanofluids are intensely dependent upon the shape and property of the additive. Therefore, sphere of nanofluid research can be extended through exploring new nanomaterials. For example, the newly discovered 2-D monatomic sheet graphene may be an exciting candidate to enhance the thermal conductivity of the base fluid. The concept of nanofluids is also extended by the use of phase change materials, which goes 
well beyond simply increasing the thermal conductivity of a fluid; for instance, it is found that the indium/polyalphaolefin phase change nanofluid exhibits simultaneously enhanced thermal conductivity and specific heat [108-110].

\section{Conclusions}

This paper has comprehensively reviewed the advancements in solar thermal technology with a special focus on performance enhancement methodologies. Following conclusions may be drawn on that basis of this study:

- Different types of solar collectors have been discussed in a simplistic manner to attract beginners in the sphere of solar thermal conversion technology. Novel approaches have been highlighted in each category to emphasize the use of solar energy for routine activities.

- The modification in surface geometry of absorber plate by the use of extended surfaces/ribs/corrugations results in enhanced performance. A particular type of geometrical modification can be selected based on energy requirement governed by the outlet temperature of working fluid. However, there are no set standards available for exact determination of types of modifications, which will result in better performance for a given condition.

- Use of solar selective coatings enhances the collector performance significantly. There is a need to develop a cost effective method to produce the coating on the absorber surface. These coatings could not be commercialized due to their high cost, low productivity, and complexity in processes.

- Use of nanofluids for heat transfer augmentation is still an emerging area. The particle size, volume fraction and $\mathrm{pH}$ value play an important role but there is considerable lack of agreement in the findings by different groups. The experimental and analytical investigations are in disagreement as far as performance dependence on aforementioned parameters is concerned. Hence, there is no universally accepted model for predicting the behavior of nanofluids.

\section{References}

[1] Kalogirou SA. Solar thermal collectors and their applications. Prog Energy Combust Sci 2004;30:231-95.

[2] Barlev D, Vidu R, Stroeve P. Innovation in concentrated solar power. Sol Energy Mater Sol Cells 2011;95:2703-25.

[3] Tang R, Sun Z, Li Z, Yu Y, Zhong H, Xia C. Experimental investigation on thermal performance of flat plate collectors at night. Energy Convers Manag 2008;49:2642-6.

[4] Tang R, Cheng Y, Wu M, Li Z, Yu Y. Experimental and modeling studies on thermosiphon domestic solar water heaters with flat-plate collectors at clear nights. Energy Convers Manag 2010;49:2548-56.

[5] Hossain MS, Saidur R, Fayaz H, Rahim NA, Islam MR, Ahamed JU, Rahman MM. Review on solar water heater collector and thermal energy performance of circulating pipe. Renew Sustain Energy Rev 2011;15:3801-12.

[6] Shukla R, Sumathy K, Erickson P, Gong J. Recent advances in the solar water heating systems: a review. Renew Sustain Energy Rev 2013;19:173-90.

[7] Shukla A, Buddhi D, Sawhney RL. Solar water heaters with phase change material thermal energy storage medium: a review. Renew Sustain Energy Rev 2009;13:2119-25.

[8] Ogueke NV, Anyanwu EE, Ekechukwu OV. A review of solar water heating systems. J Renew Sustain Energy 2009;1(043106):1-21.

[9] Jaisankar S, Ananth J, Thulasi S, Jayasuthakar ST, Sheeba KN. A comprehensive review on solar water heaters. Renew Sustain Energy Rev 2011;15:3045-50.

[10] Ghazi s, Sayigh A, Ip K. Dust effect on flat surfaces-a review paper. Renew Sustain Energy Rev 2014:33:742-51.

[11] Yeh HM, Lin TT. The effect of collector aspect ratio on the collector efficiency of flat-plate solar air heaters. Energy 1995;20:1041-7.

[12] Ammari HD, Nimir YL. Experimental and theoretical evaluation of the performance of a tar solar water heater. Energy Convers Manag 2003;44:3037-55.

[13] Alvarez G, Arce J, Lira L, Heras MR. Thermal performance of an air solar collector with an absorber plate made of recyclable aluminum cans. So Energy 2004;77:107-13.
[14] Chow TT. A review on photovoltaic/thermal hybrid solar technology. Appl Energy 2010;87:365-79.

[15] Tyagi VV, Panwar NL, Rahim NA, Kothari R. Review on solar air heating system with and without thermal energy storage system. Renew Sustain Energy Rev 2012;16:2289-303.

[16] Chamoli S, Chauhan R, Thakur NS, Saini JS. A review of the performance of double pass solar air heater. Renew Sustain Energy Rev 2012;16:481-92.

[17] Kumar R, Rosen MA. A critical review of photovoltaic-thermal solar collectors for air heating. Appl Energy 2011:88:3603-14.

[18] Ibrahim A, Othman MY, Ruslan MH, Mat S, Sopian K. Recent advances in flat plate photovoltaic/thermal (PV/T) solar collectors. Renew Sustain Energy Rev 2011:15:352-65.

[19] Sardarabadi M, Passandideh-Fard M, Heris SZ. Experimental investigation of the effects of silica/water nanofluid on PV/T (photovoltaic thermal units). Energy 2014;66:264-72.

[20] Zafar S, Dincer I. Thermodynamic analysis of a combined PV/T-fuel cell system for power, heat, fresh water and hydrogen production. Int J Hydrog Energy 2014;39:9962-72.

[21] Tang R, Gao W, Yu Y, Chen H. Optimal tilt-angles of all-glass evacuated tube solar collectors. Energy 2009;34:1387-95.

[22] Nalwanga R, Quity B, Muyanja C, Ibanez PF, McGuigan KG. Evaluation of solar disinfection of E. coli under Sub-Saharan field conditions using a $25 \mathrm{~L}$ borosilicate glass batch reactor fitted with a compound parabolic collector. Sol Energy 2014;100:195-202.

[23] Guiqiang L, Gang P, Yuehong S, Yunyun W, Jie J. Design and investigation of a novel lens-walled compound parabolic concentrator with air gap. Appl Energy 2014;125:21-7.

[24] Mousazadeh H, Keyhani A, Javadi A, Mobli H, Abrinia K, Sharifi A. A review of principle and sun-tracking methods for maximizing solar systems output. Renew Sustain Energy Rev 2009;13:1800-18.

[25] Ren L, Wei X, Lu Z, Yu W, Xu W, Shen Z. A review of available methods for the alignment of mirror facets of solar concentrator in solar thermal power system. Renew Sustain Energy Rev 2014;32:76-83.

[26] Kalogirou SA. Design and construction of one-axis sun tracking system. Sol Energy 1996:57:465-9.

[27] Garcia AF, Zarza E, Valenzuela L, Perez M. Parabolic-trough solar collectors and their applications. Renew Sustain Energy Rev 2010;14:1695-721.

[28] Price H, Lupfert E, Kearney D, Zarza E, Cohen G, Gee R, et al. Advances in parabolic trough solar power technology. J Sol Eng, Trans ASME 2002;124:109-25.

[29] Lobon DH, Valenzuela L. Impact of pressure losses in small-sized parabolictrough collectors for direct steam generation. Energy 2013;61:502-12.

[30] Arasu VA, Sornakumar T. Design, manufacture and testing of fiberglass reinforced parabola trough for parabolic trough solar collectors. Sol Energy 2007;81:1273-9.

[31] ASHRAE Standard 93. Method of testing to determine the thermal performance of solar collectors. American Society of Heating, Refrigerating and AirConditioning Engineers: Atlanta, GA; 1986.

[32] Mills DR, Morrison G, Pye J, Lievre PL. Multi-tower line focus Fresnel array project. J Sol Energy Eng, Trans ASME 2006;128(1):118-20.

[33] Sharan AM, Prateek M. Automation of minimum torque-based accurate solar tracking systems using microprocessors. J Indian Inst Sci 2006;86:415-37.

[34] Behar O, Khellaf A, Mohammedi K. A review of studies on central receiver solar thermal power plants. Renew Sustain Energy Rev 2013;23:12-39.

[35] Ho CK, Iverson BD. Review of high-temperature central receiver designs for concentrating solar power. Renew Sustain Energy Rev 2014;29:835-46.

[36] Eswaramoorthy M, Shanmugam S. The thermal performance of a low cost solar parabolic dish collector for process heat. Energy Sources 2012;34:1731-6.

[37] Li L, Dubowsky S. A new design approach for solar concentrating parabolic dish based on optimized flexible petals. Mech Mach Theory 2011;46:1536-48.

[38] Nia MH, Nejad AA, Goudarzi AM, Valizadeh M, Samadian P. Cogeneration solar system using thermoelectric module and Fresnel lens. Energy Convers Manag 2014;84:305-10.

[39] Varun Saini RP, Singal SK. A review on roughness geometry used in solar air heaters. Sol Energy 2007;81:1340-50.

[40] Bhagoria JL, Saini JS, Solanki SC. Heat transfer coefficient and friction factor correlations for rectangular solar air heater duct having transverse wedge shaped rib roughness on the absorber plate. Renew Energy 2002;25:341-69.

[41] Jaurker AR, Saini JS, Gandhi BK. Heat transfer and friction characteristics of rectangular solar air heater duct using rib-grooved artificial roughness. Sol Energy 2006;80:895-907.

[42] Lanjewar A, Bhagoria JL, Sarviya RM. Heat transfer and friction in solar air heater duct with W-shaped rib roughness on absorber plate. Energy 2011;36:4531-41.

[43] Bhushan B, Singh R. Nusselt number and friction factor correlations for solar air heaterduct having artificially roughened absorber plate. Sol Energy 2011;85:1109-18.

[44] Yadav S, Kaushal M, Varun Siddhartha. Nusselt number and friction factor correlations for solar air heater duct having protrusions as roughness elements on absorber plate. Exp Therm Fluid Sci 2013;44:34-41.

[45] Bhattacharyya S, Saha S, Saha SK. Laminar flow heat transfer enhancement in a circular tube having integral transverse rib roughness and fitted with centre-cleared twisted-tape. Exp Therm Fluid Sci 2013;44:727-35.

[46] Kumar A, Saini RP, Saini JS. Development of correlations for Nusselt number and friction factor for solar air heater with roughened duct having multi vshaped with gap rib as artificial roughness. Renew Energy 2013;58:151-63. 
[47] Kumar S, Saini RP. CFD based performance analysis of a solar air heater duct provided with artificial roughness. Renew Energy 2009;34:1285-91.

[48] Karwa R, Chauhan K. Performance evaluation of solar air heaters having vdown discrete rib roughness on the absorber plate. Energy 2010;35:398-409.

[49] García A, Vicente PG, Viedma A. Experimental study of heat transfer enhancement with wire coil inserts in laminar-transition-turbulent regimes at different Prandtl numbers. Int J Heat Mass Transf 2005;48:4640-51.

[50] Garcia A, Martin RH, Garcia JP. Experimental study of heat transfer enhancement in a flat-plate solar water collector with wire-coil inserts. Appl Therm Eng 2013;61:461-8.

[51] Jaisankar S, Radhakrishnan TK, Sheeba KN. Experimental studies on heat transfer and friction factor characteristics of forced circulation solar water heater system fitted with helical twisted tapes. Sol Energy 2009;83:194-952.

[52] Azmi WH, Sharma KV, Sarma PK, Mamat R, Anuar S. Comparison of convective heat transfer coefficient and friction factor of $\mathrm{TiO}_{2}$ nanofluid flow in a tube with twisted tape inserts. Int J Therm Sci 2014;81:84-93.

[53] Promvonge P, Pethkool S, Pimsarn M, Thianpong C. Heat transfer augmentation in a helical-ribbed tube with double twisted tape inserts. Int Commun Heat Mass Transf 2012;39:953-9.

[54] Nanan K, Thianpong C, Promvonge P, Eiamsa-ard S. Investigation of heat transfer enhancement by perforated helical twisted-tapes. Int Commun Heat Mass Transf 2014;52:106-12.

[55] Sandhu G, Siddiqui K, Garcia A. Experimental study on the combined effects of inclination angle and insert devices on the performance of a flat-plate solar collector. Int J Heat Mass Transf 2014;71:251-63.

[56] Tulchinsky D, Uvarov V, Popov I, Mandler D, Magdassi S. A novel nonselective coating material for solar thermal potential application formed by reaction between sol-gel titania and copper manganese spinel. Sol Energy Mater Sol Cells 2014;20:23-9.

[57] Kaushal DK. An overview of solar thermal devices based solar water heating systems \& the necessity of using solar selective coating. Renew Energy 1997; 10:355-61.

[58] Abbas A. Solchrome solar selective coatings-an effective way for solar water heaters globally. Renew Energy 2000;19:145-54.

[59] Schuler A, Geng J, Oelhafen P, Brunold S, Gantenbein P, Frei U. Application of titanium containing amorphous hydrogenated carbon films (a-C:H/Ti) as optical selective solar absorber coatings. Sol Energy Mater Sol Cells 2000;60:295-307.

[60] Schuler A, Videnovic IR, Oelhafen P, Brunold S. Titanium-containing amorphous hydrogenated silicon carbon films (a-Si:C:H/Ti) for durable solar absorber coatings. Sol Energy Mater Sol Cells 2001;69:271-84.

[61] Teixeira V, Sousa E, Costa MF, Nunes C, Rosa L, Carvalho MJ, et al. Spectrally selective composite coatings of $\mathrm{Cr}-\mathrm{Cr}_{2} \mathrm{O}_{3}$ and $\mathrm{Mo}-\mathrm{Al}_{2} \mathrm{O}_{3}$ for solar energy applications. Thin Solid Films 2001;392:320-6.

[62] Farooq M, Hutchins MG. A novel design in composities of various materials for solar selective coatings. Sol Energy Mater Sol Cells 2002;71:523-35.

[63] Farooq M, Hutchins MG. Optical properties of higher and lower refractive index composites in solar selective coatings. Sol Energy Mater Sol Cells 2002;71:73-83.

[64] Cindrella L. The real utility ranges of the solar selective coatings. Sol Energy Mater Sol Cells 2007;91:1898-901.

[65] Shashikala AR, Sharma AK, Bhandari DR. Solar selective black nickel-cobalt coatings on aluminum alloys. Sol Energy Mater Sol Cells 2007;91:629-35.

[66] Wazwaz A, Salmi J, Bes R. The effects of nickel-pigmented aluminium oxide selective coating over aluminium alloy on the optical properties and thermal efficiency of the selective absorber prepared by alternate and reverse periodic plating technique. Energy Convers Manag 2010;51:1679-83.

[67] Juang R, Yeh Y, Chang B, Chen W, Chung T. Preparation of solar selective absorbing coatings by magnetron sputtering from a single stainless steel target. Thin Solid Films 2010;518:5501-4.

[68] Du M, Hao L, Mi J, Lv F, Liu X, Jiang L, et al. Optimization design of $\mathrm{Ti}_{0.5} \mathrm{Al}_{0.5} \mathrm{~N}$ / $\mathrm{Ti}_{0.25} \mathrm{Al}_{0.75} \mathrm{~N} / \mathrm{AlN}$ coating used for solar selective applications. Sol Energy Mater Sol Cells 2011;95:1193-6.

[69] Du M, Liu X, Hao L, Wang X, Mi J, Jiang L, et al. Microstructure and thermal stability of $\mathrm{Al} / \mathrm{Ti}_{0.5} \mathrm{Al}_{0.5} \mathrm{~N} / \mathrm{Ti}_{0.25} \mathrm{Al}_{0.75} \mathrm{~N} / \mathrm{AlN}$ solar selective coating. Sol Energy Mater Sol Cells 2013;111:49-56.

[70] Liu Y, Wang C, Xue Y. The spectral properties and thermal stability of NbTiON solar selective absorbing coating. Sol Energy Mater Sol Cells 2012;96:131-6.

[71] Nuru ZY, Arendse CJ, Khamlich S, Maaza M. Optimization of $\mathrm{Al}_{x} \mathrm{O}_{y} / \mathrm{Pt} / \mathrm{Al}_{x} \mathrm{O}_{y}$ multilayer spectrally selective coatings for solar-thermal applications. Vacuum 2012;86:2129-35.

[72] Nuru ZY, Arendse CJ, Muller TF, Khamlich S, Maaza M. Thermal stability of electron beam evaporated $\mathrm{Al}_{x} \mathrm{O}_{y} / \mathrm{Pt} / \mathrm{Al}_{x} \mathrm{O}_{y}$ multilayer solar absorber coatings. Sol Energy Mater Sol Cells 2014;120:473-80.

[73] Khamlich S, McCrindle R, Nuru ZY, Cingo N, Maaza M. Annealing effect on the structural and optical properties of $\mathrm{Cr} / \alpha-\mathrm{Cr}_{2} \mathrm{O}_{3}$ monodispersed particles based solar absorbers. Appl Surf Sci 2013;265:745-9.

[74] Liu HD, Wan Q, Lin BZ, Wang LL, Yang XF, Wang RY, et al. The spectral properties and thermal stability of CrAlO-based solar selective absorbing nanocomposite coating. Sol Energy Mater Sol Cells 2014;122:226-32.

[75] Valleti K, Krishna DM, Joshi SV. Functional multi-layer nitride coatings for high temperature solar selective applications. Sol Energy Mater Sol Cells 2014; 121:14-21.

[76] Cespedes E, Wirz M, Sanchez-Garcia JA, Alvarez-Fraga L, Escobar-Galindo R, Prieto C. Novel Mo- $\mathrm{Si}_{3} \mathrm{~N}_{4}$ based selective coating for high temperature concentrating solar power applications. Sol Energy Mater Sol Cells 2014;122:217-25.
[77] Kumar SK, Murugesan S, Suresh S. Preparation and characterization of CuO nanostructures on copper substrate as selective solar absorbers. Mater Chem Phys 2014;143:1209-14.

[78] Ding Y, Chen H, Wang L, Yang CY, He Y, Yang W, et al. Heat transfer intensification using nanofluids. KONA Powder Part J 2007;25:23-38.

[79] Li Y, Zhou J, Tung S, Schneider E, Xi S. A review on development of nanofluid preparation and characterization. Powder Technol 2009;196:89-101.

[80] Wang X, Mujumdar AS. Heat transfer characteristics of nanofluids: a review. Int J Therm Sci 2007;46:1-19.

[81] Das SK, Putra N, Thiesen P, Roetzel W. Temperature dependence of thermal conductivity enhancement for nanofluids. J Heat Transf, Trans. ASME 2003; 125:567-74.

[82] Das SK, Putra N, Roetzel W. Pool boiling characteristics of nano-fluids. Int J Heat Mass Transf 2003;46:851-62.

[83] Das SK, Putra N, Roetzel W. Pool boiling of nano-fluids on horizontal narrow tubes. Int J Multiphase Flow 2003;29:1237-47.

[84] Ding Y, Alias H, Wen D, Williams RA. Heat transfer of aqueous suspensions of carbon nanotubes (CNT nanofluids). Int J Heat Mass Transf 2006;49:240-50.

[85] Xuan Y, Li Q. Heat transfer enhancement of nanofluids. Int J Heat Fluid Flow 2000;21:58-64.

[86] Eastman JA, Choi SUS, Li S, Yu W, Thompson LJ. Anomalously increased effective thermal conductivities of ethylene glycol-based nanofluids containing copper nanoparticles. Appl Phys Lett 2001;78:718-20.

[87] Das SK, Choi SUS, Patel HE. Heat transfer in nanofluids-a review. Heat Transf Eng 2006;27:3-19.

[88] Yu W, Xie H. A review on nanofluids: preparation, stability mechanisms, and applications. J Nanomater 2012;2012:1-17.

[89] Chen H, Ding Y. Heat transfer and rheological behaviour of nanofluids - a review. In: Wang L, editor. Advances in Transport Phenomena 2009. Berlin Heidelberg: Springer-Verlag; 2009. p. 135-77.

[90] Trisaksri V, Wongwises S. Critical review of heat transfer characteristics of nanofluids. Renew Sustain Energy Rev 2007;11:512-23.

[91] Haddad Z, Oztop HF, Abu-Nada E, Mataoui A. A review on natural convective heat transfer of nanofluids. Renew Sustain Energy Rev 2012;16:5363-78.

[92] Ahmed HE, Mohammed HA, Yusoff MZ. An overview on heat transfer augmentation using vortex generators and nanofluids: approaches and applications. Renew Sustain Energy Rev 2012;16:5951-93.

[93] Chandrasekar M, Suresh S, Senthilkumar T. Mechanisms proposed through experimental investigations on thermophysical properties and forced convective heat transfer characteristics of various nanofluids - a review. Renew Sustain Energy Rev 2012;16:3917-38.

[94] Sureshkumar R, Mohideen ST, Nethaji N. Heat transfer characteristics of nanofluids in heat pipes: a review. Renew Sustain Energy Rev 2013;20:397-410.

[95] Saidur R, Leong KY, Mohammad HA. A review on applications and challenges of nanofluids. Renew Sustain Energy Rev 2011;15:1646-68.

[96] Mahian O, Kianifar A, Kalogirou SA, Pop I, Wongwises S. A review of the applications of nanofluids in solar energy. Int J Heat Mass Transf 2013;57:582-94.

[97] Nkurikiyimfura I, Wang Y, Pan Z. Heat transfer enhancement by magnetic nanofluids - a review. Renew Sustain Energy Rev 2013;21:548-61.

[98] Kamyar A, Saidur R, Hasanuzzaman M. Application of computational fluid dynamics (CFD) for nanofluids. Int J Heat Mass Transf 2012;55:4104-15.

[99] Taylor RA, Phelan PE, Otanicar TP, Walker CA, Nguyen M, Trimble S, et al. Applicability of nanofluids in high flux solar collectors. J Renew Sustain Energy 2011;3(023104):1-15.

[100] Naphon P, Assadamongkol P, Borirak T. Experimental investigation of titanium nanofluids on the heat pipe thermal efficiency. Int Commun Heat Mass Transf 2008;35:1316-9.

[101] Hung YH, Teng TP, Lin BG. Evaluation of the thermal performance of a heat pipe using alumina nanofluids. Exp Therm Fluid Sci 2013;44:504-11.

[102] Noie SH, Heris SZ, Kahani M, Nowee SM. Heat transfer enhancement using $\mathrm{Al}_{2} \mathrm{O}_{3}$ /water nanofluid in a two-phase closed thermosyphon. Int J Heat Fluid Flow 2009;30:700-5.

[103] Saidur R, Meng TC, Said Z, Hasanuzzaman M, Kamyar A. Evaluation of the effect of nanofluid-based absorbers on direct solar collector. Int J Heat Mass Transf 2012;55:5899-907.

[104] Yousefi T, Veysi F, Shojaeizadeh E, Zinadini S. An experimental investigation on the effect of $\mathrm{Al}_{2} \mathrm{O}_{3}-\mathrm{H}_{2} \mathrm{O}$ nanofluid on the efficiency of flat-plate solar collectors. Renew Energy 2012;39:293-8.

[105] Yousefi T, Veisy F, Shojaeizadeh E, Zinadini S. An experimental investigation on the effect of MWCNT- $\mathrm{H}_{2} \mathrm{O}$ nanofluid on the efficiency of flat-plate solar collectors. Exp Therm Fluid Sci 2012;39:207-12.

[106] Yousefi T, Shojaeizadeh E, Veysi F, Zinadini S. An experimental investigation on the effect of pH variation of MWCNT- $\mathrm{H}_{2} \mathrm{O}$ nanofluid on the efficiency of flat-plate solar collector. Sol Energy 2012;86:771-9.

[107] Sokhansefat T, Kasaeian AB, Kowsary F. Heat transfer enhancement in parabolic trough collector tube using $\mathrm{Al}_{2} \mathrm{O}_{3} /$ synthetic oil nanofluid. Renew Sustain Energy Rev 2014;33:636-44.

[108] Yu W, Xie H, Bao D. Enhanced thermal conductivities of nanofluids containing graphene oxide nanosheets. Nanotechnology 2010;21(055705):1-7.

[109] Yu W, Xie H, Chen W. Experimental investigation on thermal conductivity of nanofluids containing graphene oxide nanosheets. J Appl Phys 2010;107 (094317):1-6.

[110] Han ZH, Cao FY, Yang B. Synthesis and thermal characterization of phasechangeable indium/polyalphaolefin nanofluids. Appl Phys Lett 2008;92 (243104):1-3. 